
Digitized by the Internet Archive in 2007 with funding from Microsoft Corporation 



THE MONROE DOCTRINE

AN OBSOLETE SHIBBOLETH 


\section{BOOKS BY HIRAM BINGHAM}

\section{ACROSS SOUTH AMERICA}

8vo. Cloth binding. 405 hages. Index. 80 illustrations. Mah. Price \$3.50 net; hostage 21 cents extra.

\section{JOURNAL OF AN EXPEDITION}

ACROSS VENEZUELA \& COLOMBIA

$$
\text { 1906-1907 }
$$

8vo. Cloth binding. Leather label. 287 flages. Index. 133 illustrations. Maf. Price $\$ 2.25$ net; hostage 18 cents extra. 


\title{
THE MONROE DOCTRINE
} AN OBSOLETE SHIBBOLETH

\author{
BY \\ HIRAM BINGHAM
}

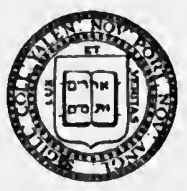

NEW HAVEN : YALE UNIVERSITY PRESS LONDON : HUMPHREY MILFORD OXFORD UNIVERSITY PRESS MDCCCCXIII 
COPYRIGHT, I 9I 3, BY YALE UNIVERSITY PRESS

FIRST PRINTED AUGUST, I 913

ONE THOUSAND FTVE HUNDRED COPIES

REPRINTED OCTOBER, 1913

ONE THOUSAND COPIES

D. B. UPDIKE, THE MERRYMOUNT PRESS, BOSTON 


\title{
UNIVERSITY OF CALIFORNLA SANTA BARBARA
}

\author{
TO \\ THE RIGHT HONOURABLE \\ JAMES BRYCE \\ IN GRATEFUL RECOGNITION \\ OF THE INSPIRATION \\ WHICH HAS COME \\ FROM HIS \\ FRIENDSHIP AND COUNSEL
}





\section{PREFACE}

For the past five years I have felt that conditions in South America were such that we ought to adopt a new foreign policy. In 1908 I learned how strongly and with how much reason the people of Argentina and Chile detested the Monroe Doctrine. Two years ago, in "Across South America," I ventured to say: "On mature consideration it does seem as though the justification for the Monroe Doctrine both in its original and its present form had passed."

In lecturing on the relations between South America and the United States, and in conversation with public men incidental to four journeys in the Southern continent, the importance of securing general recognition of the obsolete character of this national shibboleth has been borne in on me. When the Editor of the "Atlantic Monthly" asked me to put my ideas into the form of an essay I welcomed the opportunity.

The cordial response to that article is so

$$
\text { [vii] }
$$




\section{PREFACE}

significant of a decided change in public opinion that it has seemed worth while to present herewith, in more extended form than has been hitherto possible, the reasons for my belief. Naturally, this is not the place for an exhaustive treatise. The historical aspect alone might fill several volumes.

What has been attempted is to sketch the growth of the Doctrine, to indicate the obligations and disadvantages it entails, and, more particularly, to portray the attitude toward it, and toward us, of our neighbors to the south. I have also suggested, very briefly, the outlines of a new foreign policy. It is evident that the problems which are likely to arise in the future will require something more than the mere negation of outgrown doctrines.

Hiram Bingham

June, 1913. 


\section{CONTENTS}

PREFACE

PAGE vii

THE MONROE DOCTRINE 3

APPENDIX

INDEX 

THE MONROE DOCTRINE

AN OBSOLETE SHIBBOLETH 



\section{THE MONROE DOC'TRINE}

\section{2}

" THE American continents, by the free

1 and independent condition which " they have assumed and maintain, are " henceforth not to be considered as sub" "jects for future colonization by European " powers. . . . We should consider any at" tempt on their part to extend their system " to any portion of this hemisphere as dan" gerous to our peace and safety. With the " existing colonies or dependencies of any " European power, we have not interfered " and shall not interfere. But with the gov" ernments who have declared their inde" pendence, and maintained it, and whose " independence we have, on great consid" eration, and on just principles, acknow"ledged, we could not view any interposi" tion for the purpose of oppressing them, " or controlling, in any other manner, their "destiny, by any European power, in any " other light than as the manifestation of an " unfriendly disposition towards the United "States. ... ."

$$
\text { [3] }
$$


Thus, in 1823, did President James Monroe, acting under the influence of his able Secretary of State, John Quincy Adams, enunciate a doctrine which has been the most universally accepted foreign policy that we have ever had. No one questions the fact that the enunciation of this policy of "America for Americans," and our firm adherence to it for so many years, has had a very decided effect upon the history of the western hemisphere.

In the trenchant words of Mr. Root: "The famous declaration of Monroe arrayed the organized and rapidly increasing power of the United States as an obstacle to European interference and made it forever plain that the cost of European aggression would be greater than any advantage which could be won even by successful aggression.

"That great declaration was not the chance expression of the opinion or the feeling of the moment; it crystallized the sentiment for human liberty and human rights which has saved American idealism from the demoralization of narrow selfishness, and has given to American democracy its

$$
\text { [4] }
$$


true world power in the virile potency of a great example. It responded to the instinct of self-preservation in an intensely practical people."

Its significance was immediately recognized in Europe. As early as January 13, 1824, an Austrian counsellor of state commented on the Doctrine as follows: "The message of the President of the United States is an epoch-making act in the history of our times. Every line of it deserves to be considered with the most earnest attention. Not only the present attitude of that mighty and productive federation towards Europe, but also the relation of both American continents to the Old World are here enunciated with a clarity and a precision which end all doubts and duplicities. [See Appendix I.]

"The separation of America from Europe has been completed irrevocably. If the re-conquest of the colonies on the continent or their voluntary return to the old rule had not already become impossible, this opposition of the North American pcople, which has so long been developed and which has only now been openly declared would alone

$$
\text { [ } 5 \text { ] }
$$


be sufficient to banish all thoughts of it."

There have been times when ambitious European monarchs would have liked nothing better than to help themselves to poorly defended territory in what is now termed Latin America. When the Doctrine was originated, the Holy Alliance in Europe was contemplating the overthrow of republican government in Spain, and unquestionably looked with extreme aversion at the new republics in South and Central America, whose independence we were then engaged in recognizing. Russia was reaching out beyond Alaska. The firm declaration of this policy of exclusion, backed up by England's attitude toward the Holy Alliance, undoubtedly operated to give the American republics sufficient breathing-space to enable them to get on their feet and begin the difficult process of working out their own salvation, - a process which was rendered all the more difficult by reason of Hispanic racial tendencies, of centuries of autocratic colonial government, and of geographical conditions which made transportation and social intercourse extremely arduous.

$$
\text { [6] }
$$


Journeys across Peru even to-day may be beset with more difficulties than were journeys from Missouri to California sixty years ago, before the railroads. It still takes longer to go from Lima, the capital of Peru, to Iquitos, the capital of Peru's largest province, and one which the Putumayo atrocities have recently brought vividly to our notice, than it does to go from London to Honolulu.

Had it not been for the Monroe Doctrine, the American republics would have found it very much more difficult to maintain their independence during the first three-quarters of a century of their career. And this notwithstanding the fact that the actual words "Monroe Doctrine" were rarely heard or seen.

In 1845 , without mentioning this shibboleth by name, President Polk declared that the United States would not permit any European intervention on the North American continent. This, as Professor Coolidge has brought out, ${ }^{*}$ pushed the theory further

* See for an able exposition of the Monroe Doctrine, Professor A. C. Coolidge's The United States as a World Power (Macmillan).

$$
\text { [7] }
$$


than it has been carried out in practice, although it restricted the original idea by leaving South America out of account.

A few years later, while we were engaged in civil war, Napoleon III attempted to set up a European monarch in Mexico. Scarcely had we recovered, however, from the throes of our great conflict, when Mr. Seward took up with the French government the necessity for the withdrawal of the French troops from Maximilian's support. Here we were acting strongly in accordance with the best traditions of the Monroe Doctrine, and yet the mysterious words were not employed in the correspondence.

In 1866, when Chile was at war with Spain, Secretary Seward wrote to our minister in Chile: "The policy of the United States in regard to the several SpanishAmerican States is, or ought to be, well known now, after the exposition it has received during the last five years. We avoid, in all cases, giving encouragement to expectations which, in the varying course of events, we might find ourselves unable to fulfil, and we desire to be known as doing

$$
\text { [8] }
$$


more than we promise, rather than of falling short of our engagements.

"On the other hand, we maintain and insist, with all the decision and energy compatible with our existing neutrality, that the republican system which is accepted by the people in any one of those states shall not be wantonly assailed, and that it shall not be subverted as an end of a lawful war by European powers. We thus give to those republics the moral support of a sincere, liberal, and we think it will appear a useful friendship. We could claim from foreign states no concession to our own political, moral, and material principles, if we should not conform, in our own proceedings in the needful intercourse with foreign states, to the just rules of the laws of nations.

"We therefore concede to every nation the right to make peace or war for such causes, other than political or ambitious, as it thinks right and wise."

There is great dignity in Mr. Seward's words and no attempt to assume any arbitrary right to interfere in American matters.

In 1870, when General Grant was Presi-

$$
\text { [9] }
$$


dent, there arose a question relating to Santo Domingo, which led the President to insert in his message to Congress the following clause: "'The Doctrine promulgated by President Monroe has been adhered to by all political parties, and I now deem it proper to assert the equally important principle that hereafter no territory on this continent shall be regarded as subject of transfer to a European power."

It is worthy of note that the words "this continent," including in this case the island of Santo Domingo, are apparently used as synonymous with the whole of the western hemisphere.

At the same time, owing probably to the necessity of paying strict attention to our own internal affairs, following the ravages of the Civil War, it was not until the late part of the 80's and the beginning of the 90 's that we began to assume an aggressive attitude in our foreign policy.

While it was generally understood that we would not countenance any European aggressiveness or land hunger so far as the states of the western hemisphere were con-

$$
\text { [10.] }
$$


cerned, nor any political interference in the affairs of North and South America, it was not until 1895, during the second administration of President Cleveland, that a Secretary of State thought it expedient or necessary to restate the Monroe Doctrine and to bring us to the verge of a European war by backing it up with an absolutely uncompromising attitude. Venezuela had had a long-standing boundary dispute with British Guiana. Nobody cared very much either way until it was discovered that in the disputed territory were rich gold fields. In the excitement that ensued, the Venezuelans appealed to the United States, and Secretary Olney, invoking the Monroe Doctrine, brought matters to a crisis.

Our defiant attitude toward Great Britain astonished the world, and greatly pleased the majority of American citizens. The very fact that we had not the slightest personal interest in the paltry sixty thousand square miles of jungle south-east of the Orinoco added to our self-esteem. It raised our patriotism to the highest pitch when we realized that we were willing to go to war with

$$
\left[\begin{array}{lll}
1 & 1
\end{array}\right]
$$


the most powerful nation in Europe rather than see her refuse to arbitrate her right to her ancient possession of a little strip of tropical forest with a government which was not in existence when England took British Guiana, but which was an "American Republic." Fortunately for us, Lord Salisbury had a fairly good sense of humor, and declined to take the matter too seriously. Instead of standing, in the proverbial British manner, strictly for his honor and his rights, he politely ignored the Boundary Commission which we had impetuously called into existence, and, dealing directly with his neighbor Venezuela, arranged for an international court of arbitration.

We fairly shouted with joy. Even thirteen years later, one of our most widely read "syndicate journalists," writing in a fine frenzy of jingoism, summed up the Venezuela episode as follows: "Lord Salisbury and the British Government came down from their high horse, the British lion slunk away with its much twisted tail between its legs, and England agreed to arbitrate the boundary dispute. England got most of the ter-

$$
\text { [12] }
$$


ritory it claimed in the final outcome, but it got it by a judicial decree and not by force of arms. From the day that President Cleveland sent that message to Congress the nations of Europe have looked upon the United States in a different light. The Monroe Doctrine, which is the foremost positive feature of our foreign policy, is no longer a toy with which we are graciously permitted to amuse ourselves, but it is an accepted factor in international polity which commands the respect of all the world."

In our exuberance over the success of Mr. Olney's bold and unselfish enunciation of the Monroe Doctrine we failed to realize several aspects of this question. In the first place, we had proudly declared the Monroe Doctrine to be a part of international law, failing to distinguish between law and policy.

In his message transmitting the correspondence between Secretary Olney and Lord Salisbury, President Cleveland had said: " ... It may not have been admitted in so many words to the code of international law, but since in international councils every nation is entitled to the rights belonging to

$$
\text { [13] }
$$


THE MONROE DOCTRINE

it, if the enforcement of the Monroe Doctrine is something we may justly claim, it has its place in the code of international law as certainly and as securely as if it were specifically mentioned, and where the United States is a suitor before the high tribunal that administers international law, the question to be determined is whether or not we present claims which the justice of that code of law can find to be right and valid.

" The Monroe Doctrine finds its recog" nition in those principles of international " law which are based upon the theory that " every nation shall have its rights pro" tected and its just claims enforced. ..."

This sounds well and reads well - so well in fact that the average American citizen was quite convinced by it. Those who refused to accept it were later criticised by Mr. Cleveland as "un-American." He even went so far as to say: "Those among us who most loudly reprehended and bewailed our vigorous assertion of the Monroe Doctrine were the timid ones who feared personal financial loss, or those engaged in speculation and stock gambling, in buying much

$$
\text { [14] }
$$


beyond their ability to pay, and generally in living by their wits."

Yet among his critics were such able international lawyers as the late E. J. Phelps and Professor Theodore S. Woolsey. The latter wrote as follows concerning the fine rhetoric of the sentences quoted above: "There is no 'high tribunal,' no 'code of international law,' except in a metaphorical sense. If the passage means anything - which is uncertain - it means that the Monroe Doctrine is a part of the body of international law because it is in harmony with its ideas of justice. This is an error. The rules of international law are founded upon the principles of natural justice, but everything consonant with its ideas of justice is not a rule of international law."

Furthermore, Mr. Cleveland's ingenuous statement - "the principles of international law are based upon the theory that every nation shall have its rights protected and its just claims enforced" - has no legal basis. Every nation has the right of continuing and developing its existence, of giving effect to, or preserving its independence,

$$
\text { [15] }
$$


and of holding and acquiring property. It has the right to defend itself, but, as Professor Woolsey says: " .. . To say that every state has a right to be protected and to have its just claims enforced by some other state is simply ridiculous. No; it is moreit is monstrous."

We were led into taking this extreme position by the British contention that we should not seek to apply the Monroe Doctrine to the boundary dispute because it does not embody any principle of international law; and that no statesman, however eminent, and no nation, however powerful, is competent to insert into the code of international law a novel principle like the Monroe Doctrine.

In our efforts to meet this we forgot that the Doctrine had no standing as law, and was merely an exposition of our foreign policy, which, like any other policy, could be changed at our own behest if we so chose.

The American people, however, were only too willing to believe that the Monroe Doctrine was an important section of that mysterious code known as "International

$$
\text { [16] }
$$


Law," and far too large a number of us still think so.

Before leaving this aspect of the discussion it ought to be said that there were writers who even ventured to deny that the Monroe Doctrine was involved at that time. It was felt by some that where a boundary dispute arises between a European colony and an American state which the state is willing to have settled by arbitration but the mother country of the colony is not, we have noright to compel her to do so. These writers felt that to use the full extent of our power in order to force such arbitration was a view of the Monroe Doctrine " of extensive obligation, and fraught with widespread consequences."

But whether the Monroe Doctrine was or was not involved in what was known as the "Venezuela controversy " does not concern us here. The fact remains that the whole episode disclosed how widespread throughout the United States was the determination of the American people to uphold the Doctrine.

In the second place, another aspect of the

$$
[17]
$$


new version of the Monroe Doctrine which we failed to realize and whose significance we did not take the trouble to analyze was that it was founded on false premises.

We had assumed a new theorem. In the words of Mr. Olney: "The states of America, South as well as North, by geographical proximity, by natural sympathy, by similarity of Governmental Constitutions, are friends and allies, commercially and politically, of the United States."

A few years earlier, the then Secretary of State, Blaine, had brought into existence the International Union of American Republics, and had enunciated a doctrine of Pan-Americanism which has glowed more or less cheerfully ever since.

Mr. Olney's words recognized this doctrine. But when he gave "geographical proximity" as one of the reasons for this Pan-American alliance, he overlooked the fact that the largest cities of South America are geographically nearer to Spain and Portugal than to New York and New England. He failed to consider that the rich east coast of South America is no more proxi-

$$
\text { [18] }
$$


mate to the southern coast of the United States than to the southern coast of Europe; Key West is no nearer Rio Janeiro and Buenos Aires than is Gibraltar; and so far as the west coast is concerned, it actually takes longer to travel from Valparaiso, the chief South American west coast port, to San Francisco, the chief North American west coast port, than it does to go from Valparaiso to London. Peru is on the Pacific Ocean, but it is as far from Puget Sound as it is from Labrador.

Most of our statesmen studied geography when they were in the grammar school, and have rarely looked at a world-atlas since. In other words, we began the new development of the Monroe Doctrine with a false idea of the geographical basis of the PanAmerican alliance.

Furthermore, the new Monroe Doctrine was established on another false idea, the existence of "natural sympathy" between South and North America. As a matter of fact, instances might easily be multiplied to show that our South American neighbors have far more natural sympathy for, and

$$
\text { [19] }
$$


regard themselves as much more nearly akin to, the Latin races of Europe, than to the cosmopolitan people of the United States.

A recent visitor, whose ability to make careful and significant observations no one will deny, Mr. James Bryce, in summing up the question of South American affinities, writes as follows : "French literature has a double attraction for the South Americans, including the Brazilians. It gratifies their fondness for graceful and pointed and rhetorical expression. Spaniards, like Frenchmen, love style, and French style has for them a peculiar charm. With a great liking for what they call 'general ideas,' they set less store by an accumulation of facts and an elaborate examination of them than do the Germans and the English, and prefer what may be called the French way of treating a subject. In short, they have an intellectual affinity for France, for the brightness of her ideas, the gaiety of her spirit, the finish of her literary methods, the quality of her sentiment.

"Then there is Paris. When South Americans began to be rich enough to travel

$$
\text { [20] }
$$


to Europe and enjoy themselves there, Paris became the Mecca of these pilgrims of pleasure. Many a wealthy Argentine landowner, many a Brazilian coffee planter, every dictator of a Caribbean republic, who, like Guzman Blanco of Venezuela, has drawn from the public revenues funds to invest in European securities, goes to the metropolis of fashion and amusement to spend his fortune there. All the young literary men, all the young artists who can afford the journey, flock thither. There is a large South American colony in Paris, and through it, as well as through books and magazines, the French drama and art, French ideas and tastes, dominate both the fashionable and the intellectual world in the cities of South America. The writers of France have often claimed that there is something in the 'French spirit,' in their way of thinking and their way of expressing thought, which, distinctive of themselves as it is, has, nevertheless, a sort of universality, or an adaptability to the minds of all men, that has more than once in history given it an empire such as no other modern literature has enjoyed.

$$
\text { [21] }
$$


THE MONROE DOCTRINE

In and for South America this claim has been made good, for here French influence reigns supreme."

Besides this ever present affinity with France there are also strong bonds of sympathy with the mother countries. These may be readily seen in little things, straws which show the way the currents of feeling are tending.

How the Brazilians feel was seen a few years ago in Rio Janeiro, when Brazil was holding a national exposition. Each state of that great republic had a building of its own, but no foreign nations were represented, except Portugal, the mother country, which had her own building.

How Spain feels was shown recently in the case of a distinguished Spanish professor, who was able to find time to make an extended journey through Latin America, urging Pan-Hispanism, but could find no time to make a lecture tour through the cities of the United States, although offered lavish hospitality and considerable honorariums.

Of the difficulties of establishing any kind

$$
\text { [22] }
$$


of an alliance between ourselves and the South American republics no one who has travelled in South America can be ignorant. As has been well said by a recent Peruvian writer : "Essential points of difference separate the two Americas. Differences of language, and therefore of spirit; the difference between Spanish Catholicism and the multiform Protestantism of the Anglo-Saxons; between the Yankee individualism and the omnipotence of the State natural to the South. In their origin, as in their race, we find fundamental antagonisms; the evolution of the North is slow and obedient to the lessons of time, to the influences of custom; the history of the Southern peoples is full of revolution, rich with dreams of an unattainable perfection."

One of the things which make it and will continue to make it difficult for us to treat fairly with our Southern neighbors is our racial prejudice against the half-breed. As Señor Calderon bluntly says : " Half-breeds and their descendants govern the LatinAmerican republics;" and it is a well-known fact that this leads to contempt on the part

$$
\text { [23] }
$$


of the average Anglo-Saxon. In the United States a "half-white" counts as a negro. In South America he counts as a white. The difference in viewpoint is absolutely fundamental. Such a state of affairs shows the difficulty of assuming that Pan-Americanism is axiomatic, and of basing the logical growth of the Monroe Doctrine on " natural sympathy."

In the third place, the new form of the Monroe Doctrine declared, in the words of Secretary Olney, that the "United States is practically sovereign on this continent." This at once aroused the antagonism and the fear of those very Southern neighbors who, in another sentence, he had endeavored to prove were "friends and allies, commercially and politically, of the United States."

And their fears seem to have been justified by the facts.

The truth is that in the later 80 's and early 90 's, having completely recovered from the effects of the Civil War, and starting on an

$$
\text { [24] }
$$


era of great prosperity, we were "feeling our oats," as the saying goes, and were inclined to be somewhat frisky where any questions of Latin-American foreign policy were concerned.

First there was the Barrundia affair. General Barrundia, exiled from Guatemala in '85, had violated the neutrality laws of Mexico and taken passage on a United States merchantman which touched at the ports of his native land. The authorities of Guatemala demanded his surrender, but the captain of the steamer declined. The American minister and the commander of an American man-of-war in those waters were brought into the discussion. They decided that by the rules and precedents of international law the United States could not object to the exercise of local police jurisdiction over a merchantman while she was lying in the waters of another country. Guatemalan soldiers then attempted to arrest General Barrundia, who was killed in the scuffle that followed. The American minister and our naval officer had acted with absolute propriety, and yet, such was

$$
\text { [25] }
$$


the temper of the American people over this action that the minister was recalled and the officer was removed from his command with a reprimand. In other words, we virtually denied the right of Guatemala to be treated with the respect due to a free and independent state.

In 1890, during the war between Guatemala and Salvador, the good offices of the United States were tendered in an effort to mediate between the warring Central American powers. Our suggestion was not only refused, but resented ; our consulate at San Salvador was attacked, and as a result we sent two men-of-war to Salvador and forced a promise of reparation.

In 1891 we again overstepped the rules of international law, and denied the right of one of the contestants in the civil war in Chile to purchase arms on the Pacific Coast. It has always been considered lawful for merchants to sell arms to all the world, at peace or at war. Arms were sold and shipped by the steamer "Itata." 'The transaction was not a guilty one, but one of our men-of-war chased the "Itata" for thou-

$$
\text { [26] }
$$


sands of miles and finally brought her back to San Diego, where she was kept several months awaiting trial. The case against her was eventually dismissed, for she had committed no breach of international law in the judgment of our own courts. The seizure of the "Itata" was the cause of very bitter feeling arising in Chile. Aided by other events which it is not necessary to go into here, it resulted in the "Baltimore" episode, when two of our sailors on shore leave were killed in the streets of Valparaiso. We did not like the dilatory tactics of Chilean law and procedure. We refused to respect the decision of the Chilean courts, and we issued an ultimatum which, although extremely distasteful to Chile, forced her to take our view of the case. There is noquestion that the American people took an immense amount of satisfaction in riding rough-shod over Chile at that time, and did it without the slightest notion that we had given the Chileans abundant cause to feel that with us might meant right. In commenting on this episode in 1892 Professor Woolsey very justly said: " . . It means, in the first place, a

$$
\text { [27] }
$$


departure from the old and safe policy of the fathers. It means courting rather than avoiding foreign entanglements. It means one collision after another, each with its sulphurous war-cloud about it. It means the violation of former precedents, setting up new ones in their stead which may prove awkward, even dangerous. It will encourage aggressions upon weak neighbors. It will make this country hated and distrusted by its natural friends. It will weaken its commercial position on this continent, throwing trade into other channels than our own. Years must pass before Chile can forget her bitter experiences at the hands of the United States and open her arms to our trade freely. International trade is largely based on sentiment."

In 1892, owing to a revolution in Venezuela, we deemed it necessary to send two men-of-war. An American merchantman violated the paper blockade. Our consulate on the Orinoco River was attacked, and hard feelings were engendered on both sides.

In 1893, during the civil war in Brazil, five men-of-war were sent into Brazilian

$$
\text { [28] }
$$


THE MONROE DOCTRINE

waters, under the command of Admiral Benham. He had no intention of allowing the naval party in the civil war to interfere with American merchant shipping, nor of recognizing rules tacitly admitted by foreign vessels. Two United States merchantmen entered the harbor and proposed to draw up to the docks to discharge. Admiralda Gama, in charge of the naval forces, notified the masters of these vessels that they could not moor to the wharves, as the district was within the fire zone. The shipmasters appealed to Admiral Benham, who immediately ordered the merchantmen to go up to the wharves, and notified the Brazilian admiral that he would open fire upon the insurgent squadron if any interference was attempted. There were then five American men-of-war in the harbor, and the Brazilian admiral could make no effective resistance in the face of this superior force. One of his cruisers did order the merchantmen to heave-to when on their way to the docks, but the U.S. S. " Detroit" immediately fired two shots at the Brazilian vessel, and the merchantmen were allowed to proceed.

$$
\text { [ } 29 \text { ] }
$$


This action was a great blow to the prestige of the naval party in the civil war. Their strongest resource had been their ability to prevent the land forces from having communication by sea with the outside world. Partly as a result of this, the naval party lost the cause for which they were fighting. The consequent anti-American attitude of their friends and supporters may easily be imagined.

In 1894 occurred the Bluefields incident in Nicaragua, when it was necessary for us to send two men-of-war in order to prevent the banishment of hated Americans who had interfered in a local revolution.

In 1895 came the Venezuela boundary dispute and the enunciation of the new Monroe Doctrine by Secretary Olney, already described.

Our actions fitted in with his words. And we were soon to justify still further the fear and apprehension of our South American neighbors. Less than three years after the enunciation of the new Doctrine we were at war with Spain. The progress of the war in Cuba and the Spanish colonies was fol-

$$
\text { [30] }
$$


lowed in South America with the keenest interest. How profoundly it would have surprised the great American public to realize that while we were spending blood and treasure to secure the independence of another American republic, our neighbors in Buenos Aires were indulging in the most severe and caustic criticism of our motives ! This attitude can be appreciated only by those who have compared the cartoons published week after week, during the progress of the war, in this country and in Argentina. In the one, Uncle Sam is pictured as a benevolent giant, saving the poor maid, Cuba, from the jaws of the ferocious dragon, General Weyler, and his cruel mistress in Spain. In the other, Uncle Sam in the guise of a fat hog is engaged in besmirching the fair garments of the Queen of Spain in his violent efforts to gobble up her few American possessions. Representations of our actions in the Philippines are in such disgusting form that it would not be desirable to attempt to describe some of the Argentine cartoons touching upon that subject.

Our neighbors felt that a decided change

$$
\text { [ } 31]
$$


had come over the Monroe Doctrine! In 1823 we had declared that "with the existing colonies or dependencies of any European power we have not interfered, and shall not interfere" (so runs the original Monroe Doctrine). In 1898 we not only interfered, but actually took away all of Spain's colonies and dependencies, freeing Cuba, retaining for ourselves Porto Rico, Guam, and the Philippines, and eventually securing a valuable naval station at Guantanamo on the island of Cuba.

Without for a moment wishing to enter into a discussion of the wisdom of our actions, I desire to emphasize the tremendous difference between the old and the new Monroe Doctrine. This is not a case of theories and arguments, but of deeds. What are the facts?

In 1895 we declare that we are practically sovereign on this continent, and we follow up this declaration three years later, as a result of the Spanish War, by actually increasing the extent of our possessions and thoroughly justifying the alarm of our neighbors. The immediate result was to treble our difficulties throughout Latin America.

$$
\text { [32] }
$$


In the year after the war with Spain, we had trouble with Brazil over a scientific expedition to the Amazon; we were obliged to send a warship to Central American waters for the protection of American interests; we got into trouble with Ecuador over the refusal of an American consul-general to answer the serving of a summons; we made a peremptory demand on Colombia for $\$ 30,000$ for damages sustained by two newspapers in Panama, owing to their seizure by the Colombian government during a revolution; we landed troops in Nicaragua; and we felt obliged to send a warship to Venezuela to look after our interests during one of her numerous revolutions. No wonder our neighbors felt worried. Our attitude caused actions which forced us to take unpleasant measures.

In 1900 the wife of the American consul at La Guaira was attacked, and in the following year in the same port the sailors of an American warship were set upon by a mob.

In 1902 Colombia seized some American property and returned it after we had

$$
\text { [ } 33]
$$


sent a warship into Colombian waters. In the same year we intervened in Venezuelan affairs.

But one of the worst blows came in 1903, when we assisted in the establishment of the Republic of Panama, and then took control of the Canal Zone. In other words, we went through the form of preventing a South American republic from subduing a revolution in one of her distant provinces, and eventually took a strip of that province because we believed we owed it to the world to build the Panama Canal. Again, let it be clear that I am not interested at this point in defending or attacking our actions in any of these cases, - I merely desire to state what has happened, and to show some of the fruits of the new Monroe Doctrine. "By their fruits ye shall know them."

In 1906 Secretary Root made his tour of SouthAmerica, and began negotiations looking toward the accomplishment of peace among the warring states of Central America.

In 1908 two warships had to be sent to Honduras because the exequaturs of the

$$
\text { [34] }
$$


American consuls had been cancelled. In 1909 we decided that the celebrated Alsop claim, made on behalf of American citizens to whom Chile owed a certain amount of money, should be brought to the front after slumbering for many years, and an ultimatum was presented to Chile that the matter be settled at once. Chile replied by offering to submit the whole case to the King of England as arbitrator. But the amount of irritation caused by the method followed was out of all proportion to the amount of money involved.

Another one of the "fruits" which has not escaped the attention of our neighbors in South America is our intervention in Santo Domingo. For years Santo Domingo had been the scene of frequent revolutions. It was impossible for her creditors to find a satisfactory government with whom to deal for any length of time. At times, it is said, there were three "governments." Several European nations whose citizens had been victims of Santo Domingo's violated contracts were talking of seizing a custom house or so. President Roosevelt felt that the con-

$$
\text { [35] }
$$


ditions in the Dominican Republic not only constituted a menace to our relations with other foreign nations, but that they also concerned the prosperity of the people of the island and the security of American interests. The Dominican Republic was finding it impossible to defray the ordinary expenses of government and to meet its obligations. With a population of about half a million, it had a public indebtedness, not including all claims, of $\$ 32,000,000$. 'The representatives of the European governments concerned several times appealed to the Secretary of State, setting forth the wrongs and intolerable delays to which they had been subjected in the collection of their just claims, and intimating that, unless the Dominican government should receive some assistance from the United States in the way of regulating its finances, the creditor governments in Europe would be forced to take more effective means of compulsion to secure the satisfaction of their claims.

Notwithstanding this strong statement of the case, a protocol submitted by the President and providing that the United States

$$
\text { [36] }
$$


THE MONROE DOCTRINE

should attempt to adjust all the obligations of the Dominican government and should take charge of the custom houses was not ratified by the United States Senate. Another protocol, however, under which the United States accepted the control of the administration of the custom houses, but not giving us quite such extensive powers, was ratified in 1907. Thus one of the main incentives of revolution, i.e., the hope of seizing the revenues of the government, was partly cut off. There has been an occasional revolution since we took control of the custom houses, but the financial condition of the island is certainly better than it was. Thus we may seem to have been justified in our course, but the fact remains that although our intervention may have been an excellent thing for the people of Santo Domingo, it has undoubtedly interfered with their right to do as they please with their own money, and has acted as a sinister warning to other Latin-American states as to what they may expect of us if they fail to pay their debts.

Within the past three years we have twice

$$
\text { [37] }
$$


landed troops in Central America and taken an active part by way of interfering in local politics. We believed that the conditions were so bad as to justify us in carrying out the new Monroe Doctrine by aiding one side in a local revolution.

Our policy toward the republics of Central America has undergone a startling development since the beginning of President Roosevelt's administration. In the words of a recent minister to Honduras, our policy has changed "from simple mediation and scrupulous non-intervention, to a policy of active, direct intervention in their internal affairs; and secondly, these interventions have become as startlingly frequent as they have become increasingly embarrassing in character.

"The dangerous trend of such a policy towards an actual intermeddling in the administration of these countries, would seem fairly obvious. Such a result, from every point of view, whether of the United States, of the state immediately affected, or of other Spanish-American states, would be as lamentable as it would appear unnecessary."

$$
\text { [38] }
$$


Of our armed intervention in Cuba it is scarcely necessary to speak, except to refer in passing to the newspaper story, credited and believed in Cuba, that if American troops are again obliged to intervene in the political life of that country, they will not be withdrawn as has been the practice in the past.

Finally, in 1912, the Senate of the United States, by an overwhelming majority, passed the Lodge resolution which enlarges the Monroe Doctrine by declaring that " when any harbor or other place in the American continents is so situated that the occupation thereof for naval or military purposes might threaten the communication or the safety of the United States, the government of the United States could not see, without grave concern, the possession of such harbor or other places by any corporation or association which has such relation to another government not American as to give that government practical power of control for naval or military purposes."

Practically, this amounts to saying that if any American republic chooses to exercise

$$
\text { [39] }
$$


her sovereign rights and sell a harbor that is within a couple of thousand miles of the Panama Canal, we could not allow the transaction to go through without very vigorous protest; although, we ourselves, by taking the harbor of Guantanamo for a naval base, are hardly in a position to enter logical protest.

This resolution was precipitated by the rumored attempt of a Japanese fishing company to secure certain privileges on Magdalena Bay.

The fact that this enlargement of the Monroe Doctrine interferes with the natural.desires of any American republic to deal with foreign corporations, and so clashes with the sovereign rights of independent states, seems hardly to have been taken into account by the Senate. President Taft, however, did not approve of the resolution and it was not signed, but its passage by a vote of 51 to 4 is regarded in South America as evidence of our tendency to interfere in their affairs. [See Appendix IV.]

In short, many of the events of the past quarter-century have amply justified our

$$
\text { [40] }
$$


Southern neighbors in feeling that the Monroe Doctrine, under which term they include our general foreign policy in the western hemisphere, means interference and intervention.

A recent American minister to Honduras, in a carefully prepared paper before the American Political Science Association, was obliged to admit that -

"Historically, the Spanish-Americans have cherished in their hearts a marked aversion for the Yankee. The taking of California from Mexico, the occupation of Porto Rico, the protectorate over Cuba, the receivership in Santo Domingo, the coup d'état in Panama, are all held to be palpable evidence of a lust for territory and warnings of the ultimate fate awaiting other countries on this continent. Every intervention of the United States, while approred by the faction immediately favored, is viewed with apprehension by all other SpanishAmericans."

The menace of intervention, armed intervention, the threatened presence of machine guns and American marines, have repeat-

$$
\text { [41] }
$$




\section{THE MONROE DOCTRINE}

edly been used by Latin-American politicians themselves in their endeavors to keep the peace in their own countries. And we have done enough of that sort of thing to make it evident to disinterested observers that the new Monroe Doctrine, our present policy, is to act as international policeman for the Latin part of the western hemisphere.

Is this Doctrine worth while?

Let us see what it involves : first, from the European, second, from the Latin-American point of view.

\section{III}

By letting it be known in Europe that we shall not tolerate any European intervention or the landing of European troops on the sacred soil of the American republics, we assume very grave responsibilities.

As the "Spectator" recently pointed out, if France or Germany or Great Britain is offended by some act of a South American State - the Monroe Doctrine offers a way out of these difficulties. "It constitutes the United States a kind of buffer between the

$$
\text { [42] }
$$


contending parties; it provides a means of reconciling our interests and theirs without demanding an unconditional surrender on either side. But it does not do this without laying a very real burden on the United States." In other words, the Monroe Doctrine makes the United States a medium between the powers of Europe and South America.

We have even gone further than this, we have declared in the words of Secretary Olney, that the United States is " practically sovereign on this continent, and that its fiat is law upon the subject to which it confines its interposition." Therefore European countries have the right to look to us to do that which we prevent them from doing. A curious result of this is that some of the American republics float loans in Europe, believing that the United States will not allow the governments of their European creditors forcibly to collect these loans.

Personally, I believe that it ought to be an adopted principle of international law that the armed intervention of creditor nations to collect bad debts on behalf of their bankers

$$
\text { [4.3] }
$$


THE MONROE DOCTRINE

and bondholders is forbidden. ${ }^{*}$ If this principle were clearly understood and accepted, these bankers and underwriters would be far more particular to whom they loaned any great amount of money, and under what conditions. They would not be willing to take the risks which they now take, and many unfortunate financial tangles would never have a beginning. It is natural for a republic which has great undeveloped resources, much optimism, and a disregard of existing human handicaps, to desire to borrow large amounts of money in order to build expensive railroads and carry out desirable public improvements. It is equally natural that capitalists seeking good interest rates and secure investments should depend on the fact that if the debtor country attempts to default on its national loans, the government of the creditors will intervene with a strong arm. It is natural that the money should be forthcoming, even though a thorough, business-like, and scientific investigation of the possessions and

* The Second Hague Conference, in 1907, adopted a resolution favoring the limitation of the employment of force for the recovery of contract debts.

$$
\text { [44] }
$$


resources of the borrowing nation might show that the chances of her being able to pay interest, and eventually to return the capital, were highly problematical, and to be reckoned as very high risks.

Millions of dollars of such loans have been made in the past. It is perfectly evident that many of these loans cannot be repaid; that the time is coming when the creditor nations will look to us as the policeman, or "elder brother," of the western hemisphere, to see to it that the little boys pay for the candy and sweetmeats they have eaten.

The recent report of the British Corporation of Foreign Bondholders, which looks after the interests of foreigncapitalists, shows that while Ecuador and Nicaragua are on the boundary line, Guatemala and Honduras are way over on the wrong side of the fence. In the words of the report: "Another year of total default on its external debt has been carried to the discredit of the Guatemalan government. The act of Spoliation, by which the bondholders were arbitrarily robbed of the revenues specially assigned to them in consideration of the sacrifices to

$$
\text { [4.5] }
$$




\section{THE MONROE DOCTRINE}

which they were forced to submit, continues to stand as a shame and disgrace to the Republic. The Council have requested His Majesty's Government to take such steps as they may deem fit to demand the restitution to the bondholders of the security of which they have been deprived. . . . Honduras has succeeded in delaying the meeting of its foreign obligations for nearly forty years, and there are no indications at present that the Government has become convinced of the necessity of putting an end to its longcontinued default, either by accepting the co-operation of American bankers in putting its finances in'order, or by any other method."

It is currently reported that the British Foreign Office recently made urgent demands on Guatemala to take steps toward settling its constantly increasing national debt. It was reported in the English papers that Guatemala had appealed to Washington and the Monroe Doctrine. It appears to be impossible to find out exactly what happened. The worst of it is, the situation is bound to recur. Mexico has a large debt,

$$
\text { [46] }
$$


THE MONROE DOCTRINE

and, as is well known, local conditions have been growing steadily worse for the past two or three years. It is conceivable that the day may come when Mexico will default the interest on her bonds. The money is mostly owed abroad. Is it the duty of the United States to decide what the foreign bondholders may or may not do?

One cannot dodge the truth that the continuation of our support of this Doctrine implies that we will undertake to be responsible for the good behavior of all of the American nations.

The nature of this responsibility was more fully realized and more frankly expressed by President Roosevelt than by any of his predecessors. In a message to Congress in 1904, he said : "It is not true that the United States feels any land hunger or entertains any projects as regards other nations of the western hemisphere save such as are for their welfare. All that this country desires is to see the neighboring countries stable, orderly, and prosperous. Any country whose people conduct themselves well can count upon our hearty friendship. If a nation shows that it

$$
\text { [47] }
$$


THE MONROE DOCTRINE

knows how to act with reasonable efficiency and decency in social and political matters, if it keeps order and pays its obligations, it need fear no interference from the United States. Chronic wrong-doing, or an impotence which results in a general loosening of the ties of civilized society, may, in America as elsewhere, ultimately require intervention by some civilized nation, and in the western hemisphere, the adherence of the United States to the Monroe Doctrine may force the United States, however reluctantly, in flagrant cases of such wrong-doing or impotence to the exercise of an international police power. [See Appendix II.]

"Our interests and those of our Southern neighbors are in reality identical. They have great natural riches, and if within their borders the reign of law and justice obtains, prosperity is sure to come to them. While they thus obey the primary laws of civilized nations they may rest assured that they will be treated by us in a spirit of cordial and helpful sympathy. We would interfere with them only in the last resort, and then only

$$
\text { [48] }
$$


if it became evident that their inability or unwillingness to do justice at home and abroad, had violated the rights of the United States or had invited foreign aggression to the detriment of the entire body of American nations."

Again, in the following year, President Roosevelt endeavored to show his sense of our responsibility. In a message to Congress he said :"One of the most effective instruments for peace is the Monroe Doctrine as it has been and is being gradually developed by this nation and accepted by other nations. No other policy could have been as efficient in promoting peace in the western hemisphere and in giving to each nation thereon the chance to develop along its own lines. If we had refused to apply the Doctrine to changing conditions it would now be completely outworn, would not meet any of the needs of the present day, and indeed would probably by this time have sunk into complete oblivion. It is useful at home, and is meeting recognition abroad because we have adapted our application of it to meet the growing and changing needs of the hemi-

$$
\text { [49] }
$$


sphere. When we announce a policy, such as the Monroe Doctrine, we thereby commit ourselves to the consequences of the policy, and those consequences from time to time alter. It is out of the question to claim a right to shirk the responsibility for its exercise. Not only we, but all American Republics who are benefited by the existence of the Doctrine, must recognize the obligations each nation is under as regards foreign peoples no less than its duty to insist upon its own rights."

At the same time, fearing the results of thus publicly acknowledging our responsibility under the Monroe Doctrine, President Roosevelt felt it necessary to issue the following warning: "Moreover, we must make it evident that we do not intend to permit the Monroe Doctrine to be used by any nation on this continent as a shield to protect it from the consequences of its own misdeeds against foreign nations. If a republic to the south of us commits a tort against a foreign nation, such as an outrage against a citizen of that nation, then the Monroe Doctrine does not force us to interfere to prevent punishment of the tort, save to see that the punishment does

$$
\text { [50] }
$$


THE MONROE DOCTRINE

not assume the form of territorial occupation in any shape. The case is more difficult when it refers to a contractual obligation. Our own government has always refused to enforce such contractual obligations on behalf of its citizens by an appeal to arms. It is much to be wished that all foreign governments would take the same view. But they do not; and in consequence we are liable at any time to be brought face to face with disagreeable alternatives. On the one hand, this country would certainly decline to go to war to prevent a foreign government from collecting a just debt; on the other hand, it is very inadvisable to permit any foreign power to take possession, even temporarily, of the custom houses of an American republic in order to enforce the payment of its obligations; for such temporary occupation might turn into a permanent occupation. The only escape from these alternatives may at any time be that we must ourselves undertake to bring about some arrangement by which so much as possible of a just obligation shall be paid. It is far better that this country should put through

$$
\text { [51] }
$$


such an arrangement, rather than allow any foreign country to undertake it."

There is no doubt that these statements were logical and represent our justifiable responsibility so long as we maintain the Monroe Doctrine. It is true they caused great alarm in South America, and in the following year President Roosevelt found it necessary to say: "In many parts of South America there has been much misunderstanding of the attitude and purposes of the United States toward the other American republics. An idea had become prevalent that our assertion of the Monroe Doctrine implied, or carried with it, an assumption of superiority, and of a right to exercise some kind of protectorate over the countries to whose territory that doctrine applies. Nothing could be farther from the truth. Yet that impression continued to be a serious barrier to good understanding, to friendly intercourse, to the introduction of American capital and the extension of American trade. The impression was so widespread that apparently it could not be reached by any ordinary means."

$$
\text { [52] }
$$


THE MONROE DOCTRINE

To disperse this impression was part of Secretary Root's mission on his journey through South America, and he was partially successful, but the logic of the situation still remains.

If we are the big-brother-with-the-club who will not permit any outsider to spank our irritating or troublesome younger brothers, we must accept the natural corollary of keeping them in order ourselves, for we cannot allow the American family to become a nuisance. And some members of it have a decided tendency in that direction. Is this task worth while? Is there not a better way out of the difficulty?

Furthermore, Europe knows that in order to continue to execute our self-imposed and responsible mission we must run counter to the most approved principles of the law of nations.

The Right of Independence is so fundamental and so well established a principle of international law, and respect for it is so essential to the existence of national self-restraint, that armed intervention, or any other action or policy tending to place that right

$$
\text { [53] }
$$


in a subordinate position, is properly looked upon with disfavor, not only in Latin America, but by all the family of civilized nations.

The grounds upon which intervention is permitted in international law differ according to the authority one consults. But in general they are limited to the right of selfpreservation, to averting danger to the intervening state, and to the duty of fulfilling engagements. When, however, the danger against which intervention is directed is the consequence of the prevalence of ideas which are opposed to views held by the intervening state, most authorities believe that intervention ceases to be legitimate. To say that we have the right to intervene in order to modify another state's attitude toward revolutions is to ignore the fundamental principle that the right of every state to live its life in a given way is precisely equal to that of another state to live its life in another way.

In the last analysis, no intervention is legal except for the purpose of self-preservation, unless a breach of international law has taken place, or unless the family of civilized states concur in authorizing it.

$$
\text { [54] }
$$


If, then, our adherence to the Monroe Doctrine means, practically, disregard of the principles of the accepted law of nations, is it worth while to continue? Why should the United States not abandon the Monroe Doctrine, and publicly disclaim any desire to interfere in the domestic quarrels of the American republics? Why should our government not publicly state to Europe that this nation will not intervene except at the request of a Pan-American Congress, and then only in case we are one of the members which such a Congress selects for the specific purpose of quieting a certain troublesome neighbor?

\section{IV}

From the Latin-American point of view, the continuance of the Monroe Doctrine is insulting, and is bound to involve us in serious difficulties with our neighbors. We seem to be blind to actual conditions in the largest and most important parts of Latin America, such as Brazil, Argentina, and Chile. We need to arouse the average citizen to study the commercial situation and the recent his-

$$
\text { [55] }
$$


tory of those three republics. Let him ponder on the meaning of Brazil's one hundred million dollars of balance of trade in her favor. Let him realize the enormous extent of Argentina's recent growth, and her ability to supply the world with wheat, corn, beef, and mutton. Let him examine Chile's political and economic stability. Let him consider whether or not these nations are fit to take care of themselves, and are worthy of being included in an alliance to preserve America for the Americans, if that is worth while. Let him ask himself whether or not the Argentine, Brazilian, and Chilean governments deserve our patronizing, we-willprotect-you-from-Europe attitude.

We are not an imaginative people. Unlike our Southern neighbors, it is difficult for us to visualize the meaning of printed statements about countries that we have never seen. When the South American hears the figures of our commerce, learns the height of our sky-scrapers, and listens to the extent of the benefactions of our leading philanthropists, he cannot help conceiving an overpowering sense of the greatness of the United

$$
\text { [ } 56]
$$


States, and is even inclined to exaggerate its power for interference and intervention.

$\mathrm{We}$, on the other hand, really need to visit South America in order to get a vivid idea of present conditions in the leading republics. Fortunately, the number of those who travel southward is increasing every year. The Boston Chamber of Commerce took a long step in the right direction recently by making it possible for its members and friends to enjoy a comfortable tour through the leading South American cities. But individual tourists have nothing to fear. 'The luxury-loving American traveller can even find four Ritz-Carlton hotels on the east coast. The steamers that take him to them are as comfortable as any in the world. Conditions on the west coast will soon be equally good.

Furthermore, our Southern neighbors are rather more fond of certain kinds of luxury than we are, and in their present prosperous condition they seem to be abundantly able to pay. In fact, perhaps one of the best ways of getting an idea of Argentina's economic status is to look at the question of taxi-cabs.

$$
\text { [57] }
$$


New York, with a population of over 5 million, has at the present time about 2000 licensed taxi-cabs. Chicago, with a population of over 2 million, has 700 taxi-cabs. Buenos Aires, the capital of Argentina, with a population of but one million three hundred thousand, has 3000 taxi-cabs; or more than New York and Chicago combined. Do you believe she would have any less if we did away with the Monroe Doctrine?

Let us look a few facts squarely in the face, even though we cannot visualize them as sharply as the South Americans do. Our imports from China and Japan in 1910 amounted to 81 million dollars. Our imports from Argentina and Brazil amounted to 129 million dollars. In the same year there were 57 million sheep in the United States. Argentina had 67 million. In 1911 we built over 3000 miles of railroad in the United States. To be sure, Argentina did not build as much, but she did build over 2300 miles.

During the past five years we have exported 153 thousand tons of meat. Argentina has exported 1500 thousand tons or nearly ten times as much. During the past

$$
\text { [58] }
$$


THE MONROE DOCTRINE

three years, while we were exporting 118 million bushels of wheat, Argentina exported 226 million bushels or nearly twice as much. We have always considered ourselves great corn producers, and so we are, but last year while we were exporting 30 million bushels, Argentina was exporting 172 million bushels.

The total exports of Argentina for last year amounted to $\$ 480,000,000$, of which $\$ 278,000,000$ represented products of agriculture and $\$ 188,000,000$ represented pastoral products. Argentina will soon be the world's greatest purveyor of food-stuffs ; in fact, she already leads in several lines. This enables her to be a great buyer. Last year her purchases abroad amounted to $\$ 384,000,000$. It will be noticed that the balance of trade in her favor was nearly $\$ 100,000,000$.

Brazil has about the same favorable balance, and yet she is only on the threshold of her development. Last year she was only able to purchase $\$ 270,000,000$ worth of goods abroad. 'These two little republics, whom we are trying to shelter under the Monroe

$$
\text { [59] }
$$


Doctrine, together imported $\$ 650,000,000$ worth of goods last year and had about $\$ 200,000,000$ left over.

Some of my readers will be thinking, "But Argentina and Brazil are only two countries and there are eleven others in South America." And this is true, but it is also true that we have been talking about the majority, for Argentina and Brazil contain more than half the total population of South America and comprise four-sevenths of the total area. Furthermore, we have said nothing about Chile, which is by nature a small country, but has a very active population and an excellent government. Her political upheavals have been no more frequent than our own, and her record for courage and daring in time of war has not been excelled in any part of the world.

Another reason why we should focus our attention on Argentina, Brazil, and Chile is that the volume of their foreign commerce is four-fifths of the total for South America.

While Chile has not the great agricultural possibilities of her neighbors, she is nevertheless in a strong financial position.

$$
\text { [6o] }
$$


THE MONROE DOCTRINE

She has recently given contracts for harbor improvements at Valparaiso and San Antonio involving an expenditure of over $\$ 20,000,000$. She is drawing the plans for further improvements in other harbors which her Minister of Finance estimates will cost $\$ 25,000,000$ more. There is no evidence that Chile is a weakling, even if her territory is not very broad.

One thing more. The amount of British capital invested in the countries of Latin America is a fair criterion of their importance. According to the latest figures, as given in the "South American Journal," a weekly devoted to the interests of the British investor, the amount of British capital invested in Argentina amounts to about $£ 330,000,000$ or $\$ 1,610,400,000$. In Brazil Great Britain has invested $£ 211,000,000$ or $\$ 1,029,680$,000 , of which about one-half is in government bonds. In Chile she has $£ 61,000,000$ or $\$ 297,680,000$, of which one-half is in government bonds. In the whole of Latin America British investments amount to $£ 937,140,000$ or $\$ 4,573,243,200$.

Such figures really surpass our powers

$$
\text { [ } 611]
$$




\section{THE MONROE DOCTRINE}

of imagination. But even if the tops of the mountains are in the clouds, we can at least realize that we are confronted by mountains and not molehills.

Although the average American does know far more about South America than he did a few years ago, when I heard a member of one of the larger University Clubs in the East admit that he did not know whether Venezuela was in Central or South America, and cared less, we are many of us actually groping in the dark, and undoubtedly it is difficult to grasp present conditions in the three largest states of South America.

We know that they are not the hot-beds of revolutions and fevers that we once supposed them to be, and that there is something there besides earthquakes, jungles, and generals. Yet very few of us actually appreciate the present state of affairs. How many people realize, for instance, that there are twelve steamers a month sailing from New York, which carry freight, passengers, and mails to the ports of Brazil, or that there are fifty mail steamers a month between Europe and Argentina?

$$
\text { [62] }
$$




\section{THE MONROE DOCTRINE}

The fact is, we are still wofully ignorant of the actual conditions in the leading American republics. Is it not time that we began to realize why it is that to the inhabitants of those countries the very idea of the existence of the Monroe Doctrine is not only distasteful, but positively insulting?

It seems to many of them as gratuitous as it would to us if Chile were to enunciate a similar doctrine as a result of the Japanese troubles in California, and should declare that she could not view any interposition for the purpose of oppressing the Californians, or contemplate their destruction by any Asiatic power, "in any other light than as the manifestation of an unfriendly disposition" toward Chile, and "dangerous to her peace and safety." 'The day may come when we shall be glad enough to have her hold those opinions, but for her to declare them at the present time would, to say the least, seem uncalled for and strange. But it is no more uncalled for nor any stranger than that as a people we should regard the Monroe Doctrine as applying to Chile or Argentina or Brazil.

$$
\text { [63] }
$$


Surely enough has been said to make it perfectly evident that the leading powers of South America are abundantly able to take care of themselves and are in a position to laugh at the old Monroe Doctrine.

If these powers dislike and despise our maintenance of the old Monroe Doctrine, it is not difficult to conceive how much more they must resent the new one. The very thought that we, proud in the consciousness of our own self-righteousness, sit here with a smile on our faces and a big stick in our hands, ready to chastise any of the American republics that do not behave, fairly makes their blood boil. It may be denied that this is our attitude. Grant that it is not; still our neighbors believe that it is, and if we desire to convince them of the contrary, we must definitely and publicly abandon the Monroe Doctrine and enunciate a new kind of foreign policy.

The present Monroe Doctrine is simply a "petulant and insatiable imperialism," and its development is "a superb, audacious, and mortifying notification to the Latin peoples of the continent " of our stren-

$$
\text { [64] }
$$


THE MONROE DOCTRINE

uous desire either to absorb the small republics or to become the supreme arbiters of their destinies.

These are the sentiments of a learned Argentine judge, writing in one of the most important periodicals of the southern hemisphere. In an article filled with paragraphs of vigorous protest, which breathes the essence of the Southern feeling toward the MonroeDoctrine, he enlarges on this theme : "It is both convenient and necessary that we should declare in virile and dignified language to the United States that we are not disposed to admit her right of tutelage. It is too imperialistic, - too degrading to ourselves and our neighbors, who are worthy of being respected by the United States as well as by the cultivated powers of Europe. 'To be sure in our territories there still exist, in distant provinces, tribes of savages, just as in the United States. Nevertheless, we respect the right of the individual and his property, and our generous laws contain anuple guarantees and offer full privileges to aliens who desire to establish themselves on our rich lands. 'The fruit of their labors is

$$
\text { [65] }
$$


THE MONROE DOCTRINE

guaranteed to them by the justice of our courts. They themselves will be better for coming in contact with our culture, and their children are welcome in the numerous free public schools which may be found throughout South America."

He goes on to urge the states of Latin America to unite in declaring that they not only need no foreign tutelage, but will consider any attempt on our part to extend our system to any portion of Latin America as dangerous to their peace and safety. Any act of any foreign power which savors of intervention is to be regarded in no other light than as the manifestation of an unfriendly disposition toward the whole of Latin America, and he urges the states of Latin America to unite in declaring that they will refuse to recognize or grant belligerent rights to any foreign nation engaging in such intervention.

Nearly every one has heard of that violent Argentine patriot, Manuel Ugarte, who is devoting his life to a missionary campaign urging the Latin-American republics to confederate themselves and avoid being

$$
\text { [ } 66]
$$


THE MONROE DOCTRINE

absorbed by the United States. His book, " The Future of Latin-America," which has had a considerable vogue, consists largely of quotations from the bombastic utterances of imperialistic politicians in the United States. Our jingoistic editors give him abundant material with which to work on the sensitive feelings of the Latin Americans. Unfortunately, he is able to quote sentences from the speeches of our leading statesmen which lend color to his thesis. In 1906, when Mr. Taft was in President Roosevelt's Cabinet, he said, in the course of a speech: "The frontiers of the United States virtually extend to Tierra del Fuego." It may be easily imagined how this could be twisted into a declaration of ultimate imperialism.

The more thoughtful Argentines politely but firmly decline to admit that the Monroe Doctrine is applicable to their country. Consider these words of Professor Gil, of the University of La Plata: "It would not be possible to apply the Monroe Doctrine to any case connected with Argentina, without committing an offence very prejudicial to the

$$
\text { [67 j] }
$$


best interests of the United States. In its essence the Monroe Doctrine is tutelage. No such policy of tutelage could be carried out without gravely offending the very strong national feeling of this people."

Even Pan-Americanism does not interest the Argentines.

"Their newspapers and periodicals make only incidental reference to it, while the university and intellectual circles give it only cold and academic examination."

They believe that in practice our PanAmerican policy is vitiated and valueless because it is too one-sided. A recent cartoon depicts Uncle Sam disguised as a hideous spider, in whose web the sun-loving flies - the tropical American republics - are caught. Another, from the leading illustrated weekly of Buenos Aires, shows Uncle Sam as a hook-nosed cook with bony clawlike hands bending over a range on which he is cooking the fat fowl "Mexico" in a frying-pan of "Revolucion" and muttering with a saturnine grimace, "I think this bird will soon be done."

In Chile, the cartoonist depicts Samuel as

$$
\text { [68] }
$$


a fisherman, in whose basket are Porto Rico and Panama, and whose hook is baited with "Intervention." Cuba, Ecuador, and Mexico are swimming dangerously near in the muddy waters of "Revoluciones."

It is reported that even the heavily patronized moving picture shows have taken up the burden of the same song and are teaching the thoughtless South American proletariat that we are simply pirates.

Brazil, largely on account of its size (in area it is larger than the continental area of the United States), has always been more kindly in its criticism of us than many of the other countries. But even there the Monroe Doctrine has been "up to the present time regarded as a pure eccentricity of the kind for which America has become the classic source. . . . The Monroe Doctrine, as such, has no value whatever. At best it is simply another document for the benefit of those who would determine the characteristic psychology of the North American. Such a doctrine passes not only for a work very original and very Yankee, but also as being without substance as a whole. The

$$
\text { [69] }
$$


government of the United States can invoke it, and put it into force when it is to its advantage to do so, and whenever it is able to give to the formula the unanswerable validity and strength of big guns.

" As a North American doctrine, created and interpreted exclusively by the government at Washington, and by that government, through its sovereign criterion, exclusively applied, what we, nations of South America, should do is, not admit any such doctrine, and treat it, moreover, as if it did not exist."

If Brazilian editors can write like that, what can we expect of the others?

One of the more conservative writers of Latin America, who is by no means characterized by exaggerated criticisms or prejudiced misstatements, in an unusually lucid exposition of the Monroe Doctrine, pointedly remarks that it is an evolution of the primitive doctrine which in its essentials implies the actual practice of that very intervention in Latin America against which the original Doctrine of 1823 protested. He goes on to explain that this intervention, although

$$
\text { [ } 70 \text { ] }
$$




\section{THE MONROE DOCTRINE}

hanging imminent over the heads of his fellow citizens, will not fall as long as the Latin-American nations are orderly. He concludes an essay on "The Big Stick" with these cynical words : "The lion and the lamb will live peacefully as Jefferson announced, because this good lion only attacks the ewes when his hunger makes it absolutely necessary, and not because of any ardent desire to massacre the weak ones."

Finally, listen to this from a Latin-American editor: "Away then with this benevolent Monroe Doctrine! It is very far from a doctrine by which all interests may be equally protected, or may be held equally sacred in all the countries it concerns. Instead of that, it is a doctrine of absorption, and annihilates the interests of the parties affected.

"The North American doctrine of hegemony in the Latin republics will rob these peoples of their sovereignty at home and abroad. North American imperialism will force them to sacrifice their independence to the expansion of the United States over the whole continent. The Doctrine of Monroe is the shield and buckler of United States ag-

$$
\text { [ } 71]
$$


THE MONROE DOCTRINE

gression; it is a sword suspended by a hair over the Latin continent."

Can we afford to continue to give grounds for such statements?

\section{V}

The press of Latin America is not alone in sounding the note of protest against the Monroe Doctrine and of vigorous warning for the future. There are those who like to encourage them, to " egg them on."

We ought not to be blind to the fact that there are clever authors residing in Europe who take the utmost pains to make the Latin Americans believe - what they are unfortunately only too willing to believethat we desire to be not only practically, but actually, sovereign on the western hemisphere. A recent French writer, Maurice de Waleffe, writing on "The Fair Land of Central America," 'begins his book with this startling announcement of a discovery he has made: "The United States have made up their minds to conquer South America. W ashington aspires to become the capital of an enormous empire, comprising, with the

$$
\text { [72] }
$$




\section{THE MONROE DOCTRINE}

exception of Canada, the whole of the New World. Eighty million Yankees want to annex, not only forty million Spanish Americans, but such mines, forests, and agricultural riches as can be found nowhere else on the face of the globe."

Most of us, when we read those words, smile, knowing that they are not true; yet that does not affect the fact that the Latin American, when he reads them, gnashes his teeth and believes that they are only too true. If he belongs to one of the larger republics, it makes him toss his head angrily, and increases his hatred toward those "Yankis," whose manners hedespises. If he belongs to one of the smaller republics, his soul is filled with fear mingled with hatred, and he sullenly awaits the day when he shall have to defend his state against the Yankee invaders. In every case the effect produced is contrary to the spirit of peace and harmony.

In another book, which is attracting wide attention and was written by a young Peruvian diplomatist, there is a chapter entitled " The North American Peril," and it be-

$$
\text { [ } 73 \text { ] }
$$


THE MONROE DOCTRINE

gins with these significant words : "To save themselves from Yankee imperialism, the American democracies would almost accept a German alliance, or the aid of Japanese arms; everywhere the Americans of the North are feared. In the Antilles and in Central America hostility against the AngloSaxon invaders assumes the character of a Latin crusade."' This is a statement not of a theory but of a condition, set forth by a man who, while somewhat severe in his criticism of North American culture, is not unfriendly to the United States, and who remembers what his country owes to us. Yet he asserts that in the United States, " against the policy of respect for Latin liberties are ranged the instincts of a triumphant plutocracy.'"

The strident protest in this book has not gone out without finding a ready echo in South America. Even in Peru, long our best friend on the Southern continent, the leading daily papers have during the past year shown an increasing tendency to criticise our actions and suspect our motives. Their suspicion goes so far as actually to turn

$$
\text { [74] }
$$


friendly words against us. Last September a successful American diplomat, addressing a distinguished gathering of manufacturers in New York, was quoted all over South America as stating that the United States did not desire territorial expansion, but only commercial, and that the association should combat all idea of territorial expansion if any statesman proposed it, as this was the only way to gain the confidence of South America. This remark was treated as evidence of Machiavellian politics. One journalist excitedly exclaimed, "Who does not see in this paternal interest a brutal and cynical sarcasm? Who talks of confidence when one of the most thoughtful South American authorities, Francisco Garcia Calderon, gives us once more the cry, no longer premature, 'Let us be alert and on our guard against Yankeeism.','

Even the agitation against the Putumayo atrocities is misunderstood. "To no one is it a secret," says one Latin-American writer, "that all these scandalous accusations only serve to conceal the vehement desire to impress American and English influence on the

$$
\text { [75] }
$$


politics of the small countries of South America; and they can scarcely cover the shame of the utilitarian end that lies behind it all."'

Another instance of the attitude of the Latin-American press is shown in a recent article in one of the leading daily papers in Lima, the government organ. In the middle of its front page, in a two-column space, is an article with these headlines: "North American Excesses-The Terrible Lynchings - And They Talk of the Putumayo!', The gist of the article may easilybe imagined. It begins with these words: "While the Saxons of the world are producing a deafening cry over the crimes of the Putumayo, imagining them to be like a dance of death, and giving free rein to such imaginings; while the American government resolves to send a commission that may investigate what atrocities are committed in those regions, there was published, as regards the United States, in 'La Razón' of Buenos Aires, a fortnight ago, the following note, significant of the 'lofty civilization and high justice' of the great Republic of the North.' Here follows a press dispatch describing one

$$
\text { [ } 76]
$$


THE MONROE DOCTRINE

of the terrible lynchings which only too often happen in the United States. Then the Peruvian editor goes on to say, "Do we realize that in the full twentieth century, when there is not a single country in the world whose inhabitants are permitted to supersede justice by summary punishment, there are repeatedly taking place, almost daily, in the United States, lynchings like that of which we are told in the telegraphic dispatch?"

This propaganda is bearing fruit. Already there is talk of defensive alliances between various groups of states. Two, if not three, distinguished statesmen and orators are actually touring Latin America to see what can be done.

Meanwhile, conscious of our own rectitude, we believe all will come out well in the end, at the same time still clinging to our sacred shibboleths. The Monroe Doctrine "which blesses and revivifies the world" is one of the most respected of them all.

The result of our present attitude is that the leading powers of South America are already on the road toward what is known as the "A B C," a kind of triple alliance

$$
\text { [77] }
$$


THE MONROE DOCTRINE

between Argentina, Brazil, and Chile, with the definite object of opposing the encroachments of the United States.

A recent writer in a Spanish periodical, in discussing this policy, attributes it to the " instinct of self-preservation that impels the South American countries to draw together and to increase their armaments." He mentions the summary way in which we attempted to dispose of the Alsop claim as an example of how the South American republics may be treated. He feels that the slightest fault committed by any LatinAmerican power, that affects seriously the interests of any one of the great powers, generally results in the sending of an ultimatum, and in the humiliation of the LatinAmerican country.

The Spanish author further points out the significant fact that the "A B C" alliance is based on the constantly increasing naval resources of the three leading South American republics. Do we realize that Argentina will soon have in commission two of the most powerful dreadnoughts in existence, and that the construction of a third is

$$
\text { [.78] }
$$


contemplated? Yet in addition to her present battleships and protected cruisers, she has a fleet of forty torpedo boats and has been purchasing submarines. Chile has likewise contracted for two first-class dreadnoughts and is considering a third. She is also purchasing torpedo boats and submarines. Brazil has actually in commission three first-class dreadnoughts, seven cruisers, fifteen torpedo boats, and a number of submarines.

Undoubtedly our neighbors feel that they $*$ must do something to counteract that wellknown willingness of the American people to find good and sufficient reasons for interfering and intervening; for example, for relieving Mexico of 'Texas and California, for taking Porto Rico from Spain, for sending armies into Cuba, for taking Guantanamo Bay, for handling the customs receipts of Santo Domingo, for taking a strip of territory which (South Americans believe) belongs to the Republic of Colombia, for sending troops into Nicaragua, and for mobilizing an army on the Mexican frontier. (In regard to the latter point, it may be stated

$$
\text { [ } 79]
$$


THE MONROE DOCTRINE

in passing that it is not the custom for South American nations to mobilize an army on a neighbor's frontier merely because that country is engaged in civil war or revolution.)

Is it any wonder that the talk of alliances is in the air? Are we to continue holding to the Monroe Doctrine despite all warning?

VI

Is it worth our while to heed the "writing on the wall"'?

Is it not true that it is the present tendency of the Monroe Doctrine to claim that the United States is to do whatever seems to the United States good and proper so far as the western hemisphere is concerned? Is there not a dangerous tendency in our country to believe so far in our own rectitude, that we may be excused from any restrictions either in the law of nations, or in our treaty obligations, that seem unjust, trivial, or inconvenient, notwithstanding the established practices of civilized nations? Our attitude on the Panama tolls question, our former disregard of treaty rights with China, our hesitation at passing Mr. Taft's

$$
\text { [80] }
$$


THE MONROE DOCTRINE

carefully considered arbitration treaties, and our willingness to read into or read out of existing treaties whatever appears to us justifiable and proper, have aroused deep-seated suspicion in our Southern neighbors which it seems to me we should endeavor to eradicate if we have our own highest good at heart.

Are we not too much in the state of mind of Citizen Fix-it, who was more concerned with suppressing the noisy quarrels of his neighbors than with quietly solving his own domestic difficulties? Could we see ourselves as our Southern neighbors see us in the columns of their daily press, where the emphasis is still on the prevalence of murder in the United States, the astonishing continuance of lynching, the freedom from punishment of a majority of those who commit murder, our growing disregard of the rights of others, bomb outrages, strikes, riots, labor difficulties, - could we see these things with their eyes, we should realize how bitterly they resent our assumed right to intervene when they misbehave themselves, or when a local revolution becomes particularly noisy.

$$
[81]
$$


THE MONROE DOCTRINE

So firmly fixed in the Latin-American mind is the idea that our foreign policy today means intervention and interference, that comments on the splendid sanitary work being done at Panama by Colonel Gorgas are tainted with this idea.

On the west coast of South America there is a pest-hole called Guayaquil, which, as $\mathrm{Mr}$. Bryce says, "enjoys the reputation of being the pest-house of the continent, rivalling for the prevalence and malignity of its malarial fevers such dens of disease as Fontesvilla on the Pungwe River in South Africa and the Guinea coast itself, and adding to these the more swift and deadly yellow fever, which has now been practically extirpated from every other part of South America except the banks of the Amazon. . . . It seems to be high time that efforts should be made to improve conditions at a place whose development is so essential to the development of Ecuador itself.' Recent efforts on the part of far-sighted Ecuadorian statesmen to remedy these conditions by employing American sanitary engineers and taking advantage of the offers of American capital

$$
\text { [82] }
$$




\section{THE MONROE DOCTRINE}

were received by the Ecuadorian populace so ill as to cause the fall of the cabinet and the disgrace of the minister who favored such an experiment in modern sanitation.

Peru suffers from the conditions of bad health among her Northern neighbors, and yet the leading newspapers in Peru, instead of realizing how much they had to gain by having Guayaquil cleaned up, united in protesting against this symptom of "Yanki", imperialism, and applauded the action of the Ecuador mob.

Is it worth while to continue a foreign policy which makes it so difficult for things to be done, things of whose real advantage to our neighbors there is no question?

The old adage, that actions speak louder than words, is perhaps more true in Latin America than in the United States. A racial custom of saying pleasant things tends toward a suspicion of the sincerity of pleasant things when said. But there can be no doubt about actions. Latin-American statesmen smiled and applauded when Secretary Root, in the Pan-American Congress at Rio Janeiro, said: "We wish for no victories but those

$$
\text { [83] }
$$


of peace; for no territory except our own; for no sovereignty except the sovereignty over ourselves. We deem the independence and equal rights of the smallest and weakest member of the family of nations entitled to as much respect as those of the greatest empire, and we deem the observance of that respect the chief guaranty of the weak against the oppression of the strong. We neither claim nor desire any rights, or privileges, or powers that we do not freely concede to every American republic. We wish to increase our prosperity, to expand our trade, to grow in wealth, in wisdom, and in spirit, but our conception of the true way to accomplish this is not to pull down others and profit by their ruin, but to help all friends to a common growth, that we may all become greater and stronger together.

"Within a few months, for the first time, the recognized possessors of every foot of soil upon the American continents can be, and I hope will be, represented with the acknowledged rights of equal sovereign states in the great World Congress at The Hague. This will be the world's formal and

$$
\text { [84] }
$$


final acceptance of the declaration that no part of the American continents is to be deemed subject to colonization. Let us pledge ourselves to aid each other in the full performance of the duty to humanity which that accepted declaration implies; so that in time the weakest and most unfortunate of our republics may come to march with equal step by the side of the stronger and more fortunate. Let us help each other to show that for all the races of men the liberty for which we have fought and labored is the twin sister of justice and peace. Let us unite in creating and maintaining and making effective an all-American public opinion, whose power shall influence international conduct and prevent international wrong, and narrow the causes of war, and forever preserve our free lands from the burden of such armaments as are massed behind the frontiers of Europe, and bring us ever nearer to the perfection of ordered liberty. So shall come security and prosperity, production and trade, wealth, learning, the arts, and happiness for us all.

"Not in a single conference, nor by a single effort, can very much be done. You

$$
[85]
$$




\section{THE MONROE DOCTRINE}

labor more for the future than for the present; but if the right impulse be given, if the right tendency be established, the work you do here will go on among all the millions of people in the American continents long after your final adjournment, long after your lives, with incalculable benefit to all our beloved countries, which may it please God to continue free and independent and happy for ages to come."' [See Appendix III.]

To this fine appeal a Peruvian diplomat replies: ". . The art of oratory is lavish with a fraternal idealism, but strong wills enforce their imperialistic ambitions. Although fully attentive to the fair-sounding promises of the North, the statesmen of the South refuse to believe in the friendship of the Yankees."

And they felt that their suspicions of us were more than warranted by our subsequent actions in Cuba, Santo Domingo, and Nicaragua. Our ultimatum to Chile on account of the long-standing Alsop claim seemed to them an unmistakably unfriendly act, and was regarded as a virtual abandonment by Secretary Knox of the policy enun-

$$
\text { [86] }
$$




\section{THE MONROE DOCTRINE}

ciated by Secretary Root. It swept away as by a devastating flood every vestige of the smiling fields that Mr. Root had taken so much trouble to plant and cultivate.

Another unfriendly act was the neglect of our Congress to provide a suitable appropriation for the Second Pan-American Scientific Congress. Latin-American Scientific Congresses had been held in Argentina, Brazil, and Uruguay. In 1908, when it came Chile's turn, so kind was her feeling toward Secretary Root, the United States was asked to join in making the Fourth Latin-American Scientific Congress become the First PanAmerican. Every one of the four countries where the international scientists met had made a suitable, generous appropriation to cover the expenses of the meeting. Chile felt that it was worth while to make a very large appropriation in order suitably to entertain the delegates, to publish the results of the Congress, and to increase American friendship. Everything was done to make the "Yanki" delegates feel that bygones were bygones and the days of Pan-American brotherhood had come.

$$
\text { [87] }
$$


THE MONROE DOCTRINE

This First Pan-American Scientific Congress selected Washington as the place for the Second Congress, and named October, 1912 , as the appointed time for the meetings. But when our State Department asked Congress for a modest appropriation of fifty thousand dollars to meet our international obligations for this Pan-American gathering, our billion-dollar Congress decided to economize and denied the appropriation. When the matter came up again during the Congress that has just finished its sessions, the appropriation was recommended by the Committee on Foreign Affairs, but was thrown out on a technical point of order.

Now, you cannot make Latin Americans believe that the United States is so poor that we cannot afford to entertain International Scientific Congresses as Argentina, Brazil, Uruguay, and Chile havedone. They argue that there must be some other reason underlying this lack of courtesy. No pleasant words or profuse professions of friendship and regard can make the leading statesmen and scientists throughout Latin America forget that it was not possible to hold

$$
\text { [ } 88 \text { ] }
$$


THE MONROE DOCTRINE

the Second Pan-American Scientific Congress because the United States did not care to spend the money that was involved in assuming her international obligations. Nor will they forget that Chile spent one hundred thousand dollars in entertaining the First Pan-American Scientific Congress, and that the ten official delegates from the United States government enjoyed the bounteous Chilean hospitality and were shown every attention that was befitting and proper for the accredited representatives of the United States.

In short, here is a concrete case of how our present policy toward Latin America justifies the Latin-American attitude toward the country that has been maintaining the Monroe Doctrine. We have given them the right to feel that our policy is a purely selfish one, maintained for our own interest, and not concerned with promoting international goodwill - at least not when it costs any cash. Is it fair to ourselves to continue to maintain a doctrine which is open to such an interpretation?

$$
\text { [89] }
$$


THE MONROE DOCTRINE

\section{VII}

It is conceivable that there may come a day when threatened foreign invasion or racial migration will make it appear advisable for us to reassert the principles of the original doctrine of America for the Americans. At present, to be sure, the "A B C" powers regard the original Monroe Doctrine as long since outgrown, and as being merely a display of insolence and conceit on our part. With Brazil now owning the largest dreadnoughts in the world; with Argentina and Chile building equally good ones; with the fact that the European nations have long since lost their tendency toward monarchical despotism, and are in fact quite as democratic as many American republics, it does seem a bit ridiculous for us to pretend that the Monroe Doctrine is a necessary element in our foreign policy.

Nevertheless, there are those who think that the most natural outlet for the crowded Asiatic nations is to be found in South America, and that Japan and China will soon be knocking most loudly for admission.

$$
\text { [90] }
$$


THE MONROE DOCTRINE

There are already fifteen thousand Chinese in Peru. They readily assimilate with the Peruvians.

"The Chinese colony is rich and influential; it has taken firm root in this new land, while it retains undiminished its pride of race and its active sympathies for the progressive movement in China."

Peru, as well as Bolivia, Ecuador, and Colombia, is still overwhelmingly Indian in population. Dr. Hŕdlička, one of the leading authorities on American Anthropology, is of the opinion that the peoples of Northeastern Asia closely resemble the American aborigines. It seems not improbable that South America was once colonized largely by Asiatics. It seems to me equally probable that a similar movement may happen again.

A recent writer on "the Yellow Peril," Mr. Bland, for many years the London "Times" correspondent in Peking, and a leading authority on Chinese history and politics, has even ventured to predict that Asiatic "emigration to the tropical and sub-tropical countries of South America is certain to develop rapidly in proportion to the devel-

$$
\text { [91] }
$$


opment of direct means of communication which will follow from the opening of the Panama Canal. The Cantonese, held back from other fields of activity, will assuredly seek them, as rapidly as possible, in those regions of Brazil, Peru, Ecuador, Colombia, and Chile, where agricultural and other work is essentially a question of labor, and not of white labor.

"Economically speaking, the development of husbandry and industry in these regions by the labor of Orientals would appear to offer the only practical solution of problems upon which, in no small degree, depends the material welfare of the human race. Politically, however, the possibility of large numbers of Chinese and Japanese settling on the American continent opens up prospects of new racial difficulties in the future. Herein the separate interests of individual South American republics may well be found to conflict with those Pan-American or Monroe Doctrine ideas which lately found expression in the resolution of the United States Senate to forbid the acquisition by Japan of 'fishing rights' and a harbor on the

$$
\text { [92] }
$$


Mexican coast. For, where the present-day Cantonese go, as settlers, they will assuredly take root, and where they take root they will speedily increase and multiply.

"In the Chinese people's collective aversion to starvation, and in their partial but increasing perception of ways and means to avert that unpleasant end, by processes of 'peaceful penetration' beyond China's frontiers, we may perceive, I think, dimly outlined against the horizon of the future, the Yellow Peril racial."

The Asiatic question is certain to arise sooner or later in South America. At present Brazil's attitude toward the Japanese is in striking contrast to that of California. A Tokyo newspaper reports that the State of São Paulo offers abundant grants of land, the establishment of agricultural experiment stations and schools at the cost of the government, and the payment by the government of the expenses of transportation. Several Japanese agents have made a careful study of the soil and climatic conditions in São Paulo. One of these Japanese agricultural experts stated recently that there were

$$
\text { [93] }
$$




\section{THE MONROE DOCTRINE}

four thousand Japanese immigrants in Brazil, - that both government and public were decidedly friendly toward the Japanese, and that the Brazilian people entertained no prejudice against them. Furthermore, they are not discriminated against in the matter of naturalization. Any Japanese who owns land in Brazil, or who has married a Brazilian wife, may become a citizen.

Argentina is also friendly toward the Japanese. The annual commercial value of her products is over $\$ 150$ per capita, a remarkable result of the efforts of a country which still has enormous areas of unoccupied land. Nothing could give more eloquent proof of the splendor of the national patrimony. This also indicates the immense value of immigration to Argentina, as it is obvious that every citizen is of great potential importance and can be of mutual advantage both to himself and to the state.

Three years ago, speaking at a meeting in Tokyo of the South America Society, the Argentine Chargé d'Affaires is reported as praising his country as open to all the world, " unlike that great power in North

$$
\text { [94] }
$$


THE MONROE DOCTRINE

America, which closed its doors under the Monroe Doctrine."

The confusion in Baron de Marchi's mind, whereby our Asiatic exclusion policy is considered to be part of the Monroe Doctrine, shows how inclusive and representative of our foreign policy this shibboleth has become.

A French writer, looking on the turning of the tide of Asiatic emigration from North to South America, wrote in a contemporary periodical: "Perhaps the day may come when the competition of Japanese labor will provoke, here as elsewhere, rivalries and distrust; but at present it is almost nil. In this vast colonization field of Latin America the Japanese can themselves take part in the cultivation of waste lands, enlarging the circle of their activity, and promoting their interests and their influence, for the greater glory of the Land of the Rising Sun."

The incomparable ad vantages of theSouth American east coast and the tremendous possibilities here for the immigrant have led the Japanese government to subsidize a direct steamship service via the Cape of

$$
\text { [95] }
$$


THE MONROE DOCTRINE

Good Hope. Another Japanese line running via Honolulu taps the west coast. Already there is hardly a city in Peru that has not a Japanese barber shop. And the Peruvians are beginning to protest.

Is the western hemisphere to become Orientalized? The people of Asia may be welcome to-day and unwelcome to-morrow. Are they to come without limit? If we decide that they should enter, well and good; but if we decide against such a policy, we shall be in a much stronger position to carry out that plan if we have united with the "A B C" powers.

If we still fear aggression, and desire to prevent a partition of South America on the lines of the partition of Africa, let us bury the Monroe Doctrine and declare an entirely new policy, a policy that is based on intelligent appreciation of the present status of the leading American powers; let us declare our desire to join with the "A B C" powers in protecting the weaker parts of America against any imaginable aggressions by the European or Asiatic nations.

$$
\text { [96] }
$$


THE MONROE DOCTRINE

\section{VIII}

There is another side to the question : some of the defenders of the Monroe Doctrine state quite frankly that they are selfish, and that from the selfish point of view, the Monroe Doctrine should at all costs be maintained. They argue that our foreign commerce would suffer were Europe permitted to have a free hand in South America. Even on this very point it seems to me that they make a serious mistake.

You can seldom sell goods to a man who dislikes you except when you have something which is far better or cheaper than he can get anywhere else. Furthermore, if he distrusts you, he is not going to judge your goods fairly, or to view the world's market with an unprejudiced eye. This can scarcely be denied. Every one knows that a friendly smile or cordial greeting and the maintenance of friendly relations are essential to "holding one's customers." Accordingly, it seems that even from this selfish point of view, which some Americans are willing to take, it is absolutely against our own inter-

$$
\text { [97] }
$$


THE MONROE DOCTRINE

ests to maintain this elder-brother-with-thestick policy, which typifies the new Monroe Doctrine.

International trade is largely a matter of sentiment, and the Monroe Doctrine does not sell any American-made goods.

Furthermore, Germany is getting around the Monroe Doctrine, and is actually making a peaceful conquest of South America which will injure us just as much as if we had allowed her to make a military conquest of the Southern republics. She is winning South American friendship, and has planted colonies, one of which, in southern Brazil, has three hundred and fifty thousand people in it, - as large a population as that of Vermont, and nearly as large as that of Montana. She is taking pains to educate her young business men in the Spanish language, and to send them out equipped to capture Spanish American trade. We have a saying that "Trade follows the flag." Germany has magnificent steamers, flying the German flag, giving fortnightly service to every important port in South America, - ports where the American flag is practi-

$$
\text { [98] }
$$


cally never seen. She has her banks and business houses which have branches in the interior cities. By their means she is able to keep track of American commerce, to know what we are doing, and at what rates. Laughing in her sleeve at the Monroe Doctrine as an antiquated policy, which only makes it easier for her to do a safe business, Germany is engaged in the peaceful conquest of Spanish America.

To be sure, we are not standing still, and we are fighting for the same trade that she is, but our soldiers are handicapped by the presence of the very Doctrine that was intended to strengthen our position in the New World. Is this worth while?

No one has appreciated the possibilities and the advantages of sincere hearty friendship with South America more than Mr. Root. After his return from South America he made a notable speech before the TransMississippi Commercial Congress at Kansas City, on November 20, 1906, in the course of which he said:

"This is only the beginning; the coffee and rubber of Brazil, the wheat and beef

$$
\text { [99] }
$$


and hides of Argentina and Uruguay, the silver and the nitrates of Chile, the copper and tin of Bolivia, the silver and gold and cotton and sugar of Peru, are but samples of what the soil and mines of that wonderful continent are capable of yielding. Ninety-seven per cent of the territory of South America is occupied by ten independent republics living under constitutions substantially copied or adapted from our own. Under the new conditions of tranquillity and security which prevail in most of them, their eager invitation to immigrants from the Old World will not long pass unheeded. The pressure of population abroad will inevitably turn its streams of life and labor toward those fertile fields and valleys. The streams have already begun to flow; more than two hundred thousand immigrants entered the Argentine Republic last year; they are coming this year at the rate of over three hundred thousand. Many thousands of Germans have already settled in southern Brazil. They are most welcome in Brazil; they are good and useful citizens there, as they are here; I hope that many more

$$
\text { [100] }
$$


THE MONROE DOCTRINE

will come to Brazil and every other South American country, and add their vigorous industry and good citizenship to the upbuilding of their adopted home.

"With the increase of population in such a field, under free institutions, with the fruits of labor and the rewards of enterprise secure, the production of wealth and the increase of purchasing power will afford a market for the commerce of the world worthy to rank even with the markets of the Orient as the goal of business enterprise. The material resources of South America are in some important respects complementary to our own ; that continent is weakest where North America is strongest as a field for manufactures : it has comparatively little coal and iron. In many respects the people of the two continents are complementary to each other ; the South American is polite, refined, cultivated, fond of literature and of expression and of the graces and charms of life, while the North American is strenuous, intense, utilitarian. Where we have less of the cheerful philosophy which finds sources of happiness in the existing conditions of life, they

$$
\text { [101] }
$$


THE MONROE DOCTRINE

have less of the inventive faculty which strives continually to increase the productive power of man and lower the cost of manufacture. The chief merits of the peoples of the two continents are different ; their chief defects are different. Mutual intercourse and knowledge cannot fail greatly to benefit both. Each can learn from the other; each can teach much to the other, and each can contribute greatly to the development and prosperity of the other. A large part of their products find no domestic competition here; a large part of our products will find no domestic competition there. The typical conditions exist for that kind of trade which is profitable, honorable, and beneficial to both parties."'

This being so, why spoil the game by an irritating and antiquated foreign policy which makes it easier for our competitors and harder for our own merchants?

IX

At all events, let us face clearly and frankly the fact that the maintenance of the Monroe Doctrine is going to cost the United States

$$
\text { [102] }
$$


THE MONROE DOCTRINE

an immense amount of trouble, money, and men.

As has been repeatedly pointed out in Europe, the Monroe Doctrine is as strong as the American army and navy, and no stronger.

Carried out to its logical conclusion, it means a policy of suzerainty and interference which will earn us the increasing hatred of our neighbors, the dissatisfaction of Europe, the loss of commercial opportunities, and the forfeiture of time and attention which would much better be given to settling our own difficult internal problems. The continuance of adherence to the Monroe Doctrine offers opportunities to scheming statesmen to distract public opinion from the necessity of concentrated attention at home, by arousing mingled feelings of jingoism and self-importance in attempting to correct the errors of our neighbors.

If we persist in maintaining the Monroe Doctrine, we shall find that its legitimate, rational, and logical growth will lead us to an increasing number of large expenditures, where American treasure and American

$$
\text { [103] }
$$


blood will be sacrificed in efforts to remove the mote from our neighbor's eye while overlooking the beam in our own.

The character of the people who inhabit the tropical American republics is such, the percentage of Indian blood is so great, the little-understood difficulties of life in those countries are so far-reaching, and the psychological tendencies of the people so different from our own, that opportunities will continually arise which will convince us that our intervention is required if we continue to hold to the tenets of the Monroe Doctrine.

It is for us to face the question fairly, and to determine whether it is worth while to continue any longer on a road which leads to such great expenditures, and which means the loss of international friendships.

That international goodwill is a desideratum, it needs no words of mine to prove to any one. Looked at from every point of view, selfishly and unselfishly, ethically, morally, commercially, and diplomatically, we desire to live at peace with our neighbors and to promote international friendship.

In this way we shall have time to give

$$
\text { [104] }
$$


our minds to the problem of building up government by the people which shall give prosperity and peace and individual opportunity to every citizen.

In this great work we can have able assistance if we accept a reasonable and rational attitude toward the great states of South America. This mutual help may be, as Mr. Root said to the hospitable people of Bahia, "by sympathy and friendship, by intercourse, exchange of opinions and experience, each giving to the other the benefits of its success, and helping the other to find out the causes of its failures. We can both aid each other by the peaceful exchanges of trade. Our trade-yes, our trade is valuable, and may it increase; may it increase to the wealth and prosperity of both nations. But there is something more than trade; there is the aspiration to make life worth the living, that uplifts humanity. To accomplish success in this is the goal which we seek to attain. There is the happiness of life; and what is trade if it does not bring happiness to life? In this the dissimilarity of our peoples may enable us to aid each other. We of the North

$$
\text { [105] }
$$




\section{THE MONROE DOCTRINE}

are somewhat more sturdy in our efforts, and there are those who claim we work too hard. We are too strenuous in our lives. I wish that my people could gather some of the charm and grace of living in Bahia. We may give to you some added strength and strenuousness; you may give to us some of the beauty of life. I wish I could make you feel-I wish still more that I could make my countrymen feel - what delight I experience in visiting your city, and in observing the delightful combination of the bright, cheerful colors which adorn your homes and daily life, with the beautiful tones that time has given to the century-old walls and battlements that look down upon your noble bay. The combination has seemed to me, as I have looked upon it to-day, to be most remarkable, and these varying scenes of beauty have seemed to be suggestive of what nations can do for each other, some giving the beauty and the tender tones, some giving the sturdy and strenuous effort."

Coöperation, and not patronizing tutelage, should be our policy.

From the unselfish point of view, and

$$
\text { [106] }
$$


THE MONROE DOCTRINE

from the point of view of the world's peace and happiness, there seems to be no question that the Monroe Doctrine is no longer worth while.

Mr. Bryce, in an able exposition in his recent " South America," has clearly pointed out that the Spanish American's regard for the United States, and his confidence in its purposes, have never even recovered from the blow given by the Mexican War of 1846 , and the annexation of California. For many years, a political tie between ourselves and the other American republics was found, Mr. Bryce says, in our declared intention " to resist any attempt by European Powers either to overthrow republican government in any American state or to attempt annexation of its territory.' So long as any such action was feared from Europe, the protection thus promised was welcome, and the United States felt a corresponding interest in their clients. But circumstances alter cases. To-day, when apprehensions of the old kind have ranished, and when some of the South American states feel thenselves already powerful, one is told that they have

$$
\text { [107] }
$$


begun to regard the situation with different eyes. "Since there are nolonger rain-clouds coming up from the east, why should a friend, however well intentioned, insist on holding an umbrella over us? We are quite able to do that for ourselves if necessary." Mr. Bryce continues: "It is as the disinterested, the absolutely disinterested and unselfish, advocate of peace and goodwill, that the United States will have most influence in the western hemisphere, and that influence, gently and tactfully used, may be of incalculable service to mankind."

So widespread and malevolent are the agencies now at work throughout Latin America to prejudice the public against the United States, we ought to make every effort to have our real feelings known. Our foreign policy must be clearly formulated. We ought to take one road or the other, either to publicly repudiate this outgrown Monroe Doctrine, or else accept the logical consequences and hold ourselves responsible for the maintenance of law and order throughout the Latin-American republics. 'This last is such an enormous, not to say impertinent,

$$
\text { [ } 108]
$$


undertaking, that it is really unthinkable. Why should we not definitely abandon a doctrine which is regarded with deep resentment and ill-concealed antagonism by many of the best citizens of South America, and which enables Europe to hold us responsible for the actions of any member of the lawless group near the Caribbean Sea?

\section{$\mathrm{X}$}

Finally, if we agree to turn our backs on the Monroe Doctrine, whither shall we go? What road shall we take in order to secure the friendship of our neighbors? How can we show them that we wish to be an "absolutely disinterested and unselfish advocate of peace and goodwill"?

These are questions that require most serious thought and attention. I cannot pretend to have found the best solution for this knotty problem. It has been suggested that we form an alliance with the "A B C" powers.

It will not be easy to secure such an alliance. 'They will answer that such a proposal is only another method of imperialistic ab-

$$
\text { [ } 109]
$$


sorption. There must be no halfway measures. No doubt whatever must be allowed to remain that we are really in earnest. As a starter we might let it be known that we should be glad to exchange ambassadors with Argentina and Chile as well as with Brazil and Mexico. This would show that we have learned to regard them as worthy of respect.

This could be followed by other acts of international courtesy which would soon pave the way for a friendly alliance that should take the place of the Monroe Doctrine.

Incidentally, we might do well to assume with the best grace we may our obligations to provide handsomely for the Second PanAmerican Scientific Congress.

Furthermore, the very next time any awkward situations arise in one of the less firmly established republics, let us at once call a family gathering and see what, if anything, needs to be done.

If it is necessary to maintain order in some of the weaker and more restless republics, why not let the decision be made, not by ourselves, but by a Congress of leading American powers? If it is found necessary

$$
\text { [1 } 10]
$$


THE MONROE DOCTRINE

to send armed forces into Central America to quell rebellions that are proving too much for the recognized governments, why not let those forces consist not solely of American marines, but of the marines of Argentina, Brazil, and Chile as well?

As a matter of fact, it would be better to ask one of their squadrons to act alone, as the representative of the family. The important thing is - we must show our good faith. They doubt us. It must be our business to convince them of our integrity.

Old ideas, proverbs, catchwords, national shibboleths, die hard. No part of our foreign policy has ever been so continuously held and so popularly accepted as the Monroe Doctrine. Hoary with age, it has defied the advance of commerce, the increase of transportation facilities, and the subjugation of the yellow-fever mosquito. Based on a condition that has long since disappeared, owing its later growth and development to mistaken ideas, it appears to our South American neighbors to be neither disinterested nor unselfish, but rather an indisput-

$$
\text { [ } 1111]
$$


THE MONROE DOCTRINE

able evidence of our overweening national conceit. The very words "Monroe Doctrine", are fraught with a disagreeable significance from our neighbors' point of view. There is no one single thing, nor any group of things, that we could do to increase the chances of peace and harmony in the western hemispherecomparable with the definite statement that we have outgrown the Monroe Doctrine, that we realize that our neighbors in the New World are well able to take care of themselves, and that we shall not interfere in their politics or send arms into their territory, unless cordially invited to do so, and then only in connection with, and by the cooperation of, other members of the family.

In some such way as this we can convince " "the other Americans" of our good faith, and of the fact that we have not "made up our minds to conquer South America.' By adopting a foreign policy along these lines we can establish on a broad and solid foundation the relations of international peace and goodwill for which the time is ripe, but which cannot arrive till we are convinced that the Monroe Doctrine is not worth while.

$$
\text { [ } 112 \text { ] }
$$




\section{APPENDIX}

\section{DOCUMENTS}

ILLUSTRATIVE OF THE GROWTH OF THE MONROE DOCTRINE.

I. The Original Doctrine.

II. Excerpts from Messages of President Roosevelt, showing the logical development of the new Monroe Doctrine during his administration.

III. The Monroe Doctrine at its best, - being the speech of Secretary Root at Rio de Janeiro, July $31,1906$.

IV. The Last Phase, — the Lodge Resolution. 



\section{I \\ SELECTED PARAGRAPHS}

FROM THE SEVENTH ANNUAL MESSAGE

OF PRESIDENT JAMES MONROE

Washington, December 2, 1823.

Feulow-Crrizens of the Senate and House of Representatives : Many important subjects will claim your attention during the present session, of which I shall endeavor to give, in aid of your deliberations, a just idea in this communication. I undertake this duty with diffidence, from the vast extent of the interests on which I have to treat and of their great importance to every portion of our Union. I enter on it with zeal from a thorough conviction that there never was a period since the establishment of our Revolution, when, regarding the condition of the civilized world and its bearing on us, there was greater necessity for devotion in the public servants to their respective duties, or for virtue, patriotism, and union in our constituents.

Meeting in you a new Congress, I deem it proper to present this view of public affairs in greater detail than might otherwise be necessary. I do it, however, with peculiar satisfaction, from a knowledge that in this respect I shall comply more fully with the sound principles of our Government. The people being with us exclusively the sovereign, it is indispensable that full information be laid before them on all important subjects, to enable them to exercise that high power with complete effect. If kept in the dark, they must be incompetent to it. We are all liable to emor, and those who are engaged in the management of public affairs

$$
\text { [ } 115 \text { ] }
$$




\section{APPENDIX}

are more subject to excitement and to be led astray by their particular interests and passions than the great body of our constituents, who, living at home in the pursuit of their ordinary avocations, are calm but deeply interested spectators of events and of the conduct of those who are parties to them. To the people every department of the Government and every individual in each are responsible, and the more full their information the better they can judge of the wisdom of the policy pursued and the conduct of each in regard to it. From their dispassionate judgment much aid may always be obtained, while their approbation will form the greatest incentive and most gratifying reward for virtuous actions, and the dread of their censure the best security against the abuse of their confidence. Their interests in all vital questions are the same, and the bond, by sentiment as well as by interest, will be proportionably strengthened as they are better informed of the real state of public affairs, especially in difficult conjectures. It is by such knowledgethat local prejudices and jealousies are surmounted, and that a national policy, extending its fostering care and protection to all the great interests of our Union, is formed and steadily adhered to.

A precise knowledge of our relations with foreign powers as respects our negotiations and transactions with each is thought to be particularly necessary. Equally necessary is it that we should form a just estimate of our resources, revenue, and progress in every kind of improvement connected with the national prosperity and public defence. It is by rendering justice to other nations that we may expect it from them. It is by our ability to resent injuries and redress wrongs that we may avoid them.

$$
[116]
$$




\section{APPENDIX}

At the proposal of the Russian Imperial Government, made through the minister of the Emperor residing here, a full power and instructions have been transmitted to the minister of the United States at St. Petersburg to arrange by amicable negotiation the respective rights and interests of the two nations on the northwest coast of this continent. A similar proposal had been made by His Imperial Majesty to the Government of Great Britain, which has likewise been acceded to. The Government of the United States has been desirous by this friendly proceeding of manifesting the great value which they have invariably attached to the friendship of the Emperor and their solicitude to cultivate the best understanding with his Government. In the discussions to which this interest has given rise and in the arrangements by which they may terminate, the occasion has been judged proper for asserting, as a principle in which the rights and interests of the United States are involved, that the American continents, by the free and independent condition which they have assumed and maintain, are henceforth not to be considered as subjects for future colonization by any Ekropean powers.

The ministers who were appointed to the Republics of Colombia and Buenos Ayres during the last session of Congress proceeded shortly afterwards to their destiuations. Of their arrival there official intelligence has not yet been received. The minister appointed to the Republic of Chile will sail in a few days. An carly appointment will also be made to Mexico. A minister has been received from Colombia, and the other Governments have been informed that ministers, or diplomatic agents of inferior grade, would be received from

$$
\left[\begin{array}{lll}
1 & 1 & 7
\end{array}\right]
$$


each, accordingly as they might prefer the one or the other.

The minister appointed to Spain proceeded soon after his appointment for Cadiz, the residence of the Sovereign to whom he was accredited. In approaching that port the frigate which conveyed him was warned off by the commander of the French squadron by which it was blockaded and not permitted to enter, although apprised by the captain of the frigate of the public character of the person whom he had on board, the landing of whom was the sole object of his proposed entry. This act, being considered an infringement of the rights of ambassadors and of nations, will form a just cause of complaint to the Government of France against the officer by whom it was committed.

A strong hope has been long entertained, founded on the heroic struggle of the Greeks, that they would succeed in their contest and resume their equal station among the nations of the earth. It is believed that the whole civilized world take a deep interest in their welfare. Although no power has declared in their favor, yet none, according to our information, has taken part against them. Their cause and their name have protected them from dangers which might ere this have overwhelmed any other people. The ordinary calculations of interest and of acquisition with a view to aggrandizement, which mingles so much in the transactions of nations, seem to have had no effect in regard to them. From the facts which have come to our knowledge there is good cause to believe that their enemy has lost forever all dominion over them; that Greece will become again an independent nation. That she may obtain that rank is theobject of our most ardent wishes.

$$
\text { [ } 118 \text { ] }
$$




\section{APPENDIX}

It was stated at the commencement of the last session that a great effort was then making in Spain and Portugal to improve the condition of the people of those countries, and that it appeared to be conducted with extraordinary moderation. It need scarcely be remarked that the result has been so far very different from what was then anticipated. Of events in that quarter of the globe, with which we have so much intercourse and from which we derive our origin, we have always been anxious and interested spectators. The citizens of the United States cherish sentiments the most friendly in favor of the liberty and happiness of their fellow men on that side of the Atlantic. In the wars of the European powers in matters relating to themselves we have never taken any part, nor does it comport with our policy so to do. It is only when our rights are invaded or seriously menaced that we resent injuries or make preparation for our defence. With the movements in this hemisphere we are of necessity more immediately connected, and by causes which must be obvious to all enlightened and impartial observers. The political system of the allied powers is essentially different in this respect from that of America. This difference proceeds from that which exists in their respective Governments; and to the defence of our own, which has been achieved by the loss of so much blood and treasure, and matured by the wisdom of their most enlightened citizens, and under which we have enjoyerl unexampled felicity, this whole nation is devoted. We owe it, therefore, to candor and to the amicable relations existing between the United States and those powers to declare that we should consider any attempt on their part to extend their system to any portion of

$$
\text { [ } 11.9]
$$




\section{APPENDIX}

this hemisphere as dangerous to our peace and safety. With the existing colonies or dependencies of any European power we have not interfered and shall not interfere. But with the Governments who have declared their independence and maintained it, and whose independence we have, on great consideration and on just principles, acknowledged, we could not view any interposition for the purpose of oppressing them, or controlling in any other manner their destiny, by any European power in any other light than as the manifestation of an unfriendly disposition toward the United States. In the war between those new Governments and Spain, we declared our neutrality at the time of their recognition, and to this we have adhered, and shall continue to adhere, provided no change shall occur which, in the judgment of the competent authorities of this Government, shall make a corresponding change on the part of the United States indispensable to their security.

The late events in Spain and Portugal shew that Europe is still unsettled. Of this important fact no stronger proof can be adduced than that the allied powers should have thought it proper, on any principle satisfactory to themselves, to have interposed by force in the internal concerns of Spain. To what extent such interposition may be carried, on the same principle, is a question in which all independent powers whose governments differ from theirs are interested, even those most remote, and surely none more so than the United States. Our policy in regard to Europe, which was adopted at an early stage of the wars which have so long agitated that quarter of the globe, nevertheless remains the same, which is, not to interfere in the internal concerns of any of its powers; to consider the

$$
\text { [120] }
$$




\section{APPENDIX}

government de facto as the legitimate government for us; to cultivate friendly relations with it, and to preserve those relations by a frank, firm, and manly policy, meeting in all instances the just claims of every power, submitting to injuries from none. But in regard to those continents circumstances are eminently and conspicuously different. It is impossible that the allied powers should extend their political system to any portion of either continent without endangering our peace and happiness; nor can any one believe that our southern brethren, if left to themselves, would adopt it of their oun accord. It is equally impossible, therefore, that we should behold such interposition in any form with indifference. If we look to the comparative strength and resources of Spain and those new Governments, and their distance from each other, it must be obvious that she can never subdue them. It is still the true policy of the United States to leave the parties to themselves, in the hope that other powers will pursue the same course. (Richardson, The Messages and Papers of the Presidents, vol. 2, pp. 207-219.)

\section{II}

\section{EXCERPTS}

FROM THE MESSAGES OF PRESIDENT ROOSEVELT SHOWING THE LOGICAL DEVELOPMENT OF THE NEW MONROE DOCTRINE DURING HIS ADMINISTRATION

The Monroe Doctrine should be the cardinal feature of the foreign policy of all the nations of the two Americas, as it is of the Uniterl States. Just seventy-cight

$$
\left[\begin{array}{lll}
1 & 21 & 1
\end{array}\right]
$$




\section{APPENDIX}

years have passed since President Monroe in his annual message announced that "The American continents are henceforth not to be considered as subjects for future colonization by any European power." In other words, the Monroe Doctrine is a declaration that there must be no territorial aggrandizement by any nonAmerican power at the expense of any American power on American soil. It is in no wise intended to give cover to any aggression by one New World at the expense of any other. It is simply a step, and a long step, toward assuring the universal peace of the world by securing the possibility of permanent peace on this hemisphere.

During the past century other influences have established the permanence and independence of the smaller states of Europe. Through the Monroe Doctrine we hope to be able to safeguard like independence and secure like permanence for the lesser among the New World nations.

This doctrine has nothing to do with the commercial relations of any American power, save that it in truth allows each one of them a guaranty of the commercial independence of the Americas. We do not ask under this doctrine for any exclusive commercial dealings with any other American state. We do not guarantee any state against punishment if it misconducts itself, provided that punishment does not take the form of the acquisition of territory by any non-American power.

Our attitude in Cuba is sufficient guaranty of our own good faith. We have not the slightest desire to secure any territory at the expense of any of our neighbors. We wish to work with them hand in hand so that all

$$
\text { [122] }
$$




\section{APPENDIX}

of us may be uplifted together, and we rejoice over the good fortune of any of them, we gladly hail their material prosperity, and political stability, and are concerned and alarmed if any of them fall into industrial or political chaos. We do not wish to see any Old World military power grow up on this continent, or to be compelled to become a military power ourselves. The peoples of the Americas can prosper best if left to work out their own salvation in their own way. (57th Congress, 1st session, 1901-1902, House Documents, vol. 1, No. 1, Foreign Relations, No. 4268.)

\section{(b)}

It is not true that the United States feels any land hunger or entertains any projects as regards the other nations of the Western Hemisphere save such as are for their welfare. All that this country desires is to see the neighboring countries stable, orderly, and prosperous. Any country whose people conduct themselves well can count upon our hearty friendship. If a nation shows that it knows how to act with reasonable efficiency and decency in social and political matters, if it keeps order and pays its obligations, it need fear no interference from the United States. Chronic wrongdoing, or an impotence which results in a general loosening of the ties of civilized society, may in America as elsewhere, ultimately require intervention by some civilized nation, and in the Western Hemisphere, the adherence of the United States to the Monroe Doctrine may force the United States, however reluctantly, in flagrant cases of such wrongdoing or impotence, to the exercise of an international police power. If every country washed by the Caribbean Sea would show the

$$
\text { [ } 123]
$$




\section{APPENDIX}

progress in stable and just civilization which, with the aid of the Platt Amendment, Cuba has shown since our troops left the island, and which so many of the republics in both Americas are constantly and brilliantly showing, all questions of interference by this Nation with their affairs would be at an end. Our interests and those of our southern neighbors are in reality identical. They have great natural riches, and if within their borders the reign of law and justice obtains, prosperity is sure to come to them. While they thus obey the primary laws of civilized nations they may rest assured that they will be treated by us in a spirit of cordial and helpful sympathy. We would interfere with them only in the last resort, and then only if it became evident that their inability or unwillingness to do justice at home and abroad had violated the rights of the United States or had invited foreign aggression to the detriment of the entire body of American nations. It is a mere truism to say that every nation, whether in America or anywhere else, which desires to maintain its freedom, its independence, must ultimately realize that the rights of such independence cannot be separated from the responsibility of making good use of it.

In asserting the Monroe Doctrine, in taking such steps as we have taken in regard to Cuba, Venezuela, and Panama, and in endeavoring to circumscribe the theatre of the war in the Far East, and to secure the open door in China, we have acted in our own interest as well as in the interest of humanity at large. (58th Congress, $3 d$ session, 1904-1905, House Documents, vol. 1, No. 1, Foreign Relations, No. 4780.)

\section{$[124]$}




\section{APPENDIX}

(c)

One of the most effective instruments for peace is the Monroe Doctrine as it has been and is being gradually developed by this Nation and accepted by other nations. No other policy could have been as efficient in promoting peace in the Western Hemisphere and in giving to each nation thereon the chance to develop along its own lines. If we had refused to apply the Doctrine to changing conditions, it would now be completely outworn, would not meet any of the needs of the present day, and indeed would probably by this time have sunk into complete oblivion. It is useful at home, and is meeting recognition abroad, because we have adapted our application of it to meet the growing and changing needs of the hemisphere. When we announce a policy, such as the Monroe Doctrine, we thereby commit ourselves to the consequences of the policy, and those consecuences from time to time alter. It is out of the question to claim a right to shirk the responsibility for its exercise. Not only we, but all American Republics who are benefited by the existence of the Doctrine, must recognize the obligations each nation is under as regards foreign peoples no less than its duty to insist upon its own rights.

That our rights and interests are deeply concerned in the maintenance of the Doctrine is so clear as hardly to need argument. This is especially true in view of the construction of the Panama Canal. As a mere matter of self-defence we must exercise a close watch over the approaches to this canal; and this means that we must be thoroughly alive to our interests in the Caribbean Sea.

There are certain essential points which must never

$$
[125]
$$




\section{APPENDIX}

be forgotten as regards the Monroe Doctrine. In the first place we must as a nation make it evident that we do not intend to treat it in any shape or way as an excuse for aggrandizement on our part on the republics to the south. We must recognize the fact that in some South American countries there has been much suspicion lest we should interpret the Monroe Doctrine as in some way inimical to their interests, and we must try to convince all the other nations of the continent once and for all that no just and orderly government has anything to fear from us. There are certain republics to the south of us which have already reached such a point of stability, order, and prosperity, that they themselves, though as yet hardly consciously, are among the guarantors of this Doctrine. These republics we now meet not only on a basis of entire equality, but in a spirit of frank and respectful friendship which we hope is mutual. If all the republics to the south of us will only grow as those to which I allude have already grown, all need for us to be the especial champions of the Doctrine will disappear, for no stable and growing American Republic wishes to see some great non-A merican military power acquire territory in its neighborhood. All that this country desires is that the other republics on the continent shall be happy and prosperous; and they cannot be happy and prosperous unless they maintain order within their boundaries and behave with a just regard for their obligations toward outsiders. It must be understood that under no circumstances will the United States use the Monroe Doctrine as a cloak for territorial aggression. We desire peace with all the world, but perhaps most of all with the other peoples of the American Continent. There

$$
\text { [126] }
$$




\section{APPENDIX}

are of course limits to the wrongs which any self-respecting nation can endure. It is always possible that wrong actions toward this Nation, or toward citizens of this Nation, in some State unable to keep order among its own people, unable to secure justice from outsiders, and unwilling to do justice to those outsiders who treat it well, may result in our having to take action to protect our rights; but such action will not be taken with a view to territorial aggression, and it will be taken at all only with extreme reluctance and when it has become evident that every other resource has been exhausted.

Moreover, we must make it evident that we do not intend to permit the Monroe Doctrine to be used by any nation on this continent as a shield to protect it from the consequences of its own misdeeds against for eign nations. If a republic to the south of us commits a tort against a foreign nation, such as an outrage against a citizen of that nation, then the Monroe Doctrine does not force us to interfere to prevent punishment of the tort; save to see that the punishment does not assume the form of territorial occupation in any shape. The case is more difficult when it refers to a contractual obligation. Our own government has always refused to enforce such contractual obligations on behalf of its citizens by an appeal to arms. It is much to be wished that all foreign governments would take the same view. But they do not; and in conserjuence we are liable at any time to be brought face to face with disagreeable alternatives. On the one hand, this country would certainly decline to go to war to prevent a foreign government from collecting a just debt; on the other hand, it is very inadvisable to permit any foreign power to take

$$
[127]
$$




\section{APPENDIX}

possession, even temporarily, of the custom-houses of an American Republic in order to enforce the payment of its obligations; for such temporary occupation might turn into a permanent occupation. The only escape from these alternatives may at any time be that we must ourselves undertake to bring about some arrangement by which so much as possible of a just obligation shall be paid. It is far better that this country should put through such an arrangement, rather than allow any foreign country to undertake it. To do so insures the defaulting republic from having to pay debts of an improper character under duress, while it also insures honest creditors of the republic from being passed by in the interest of dishonest or grasping creditors. Moreover, for the United States to take such a position offers the only possible way of insuring us against a clash with some foreign power. The position is therefore in the interest of peace as well as in the interest of justice. It is of benefit to our people; it is of benefit to foreign peoples; and most of all, it is really of benefit to the people of the country concerned.

This brings me to what should be one of the fundamental objects of the Monroe Doctrine. We must ourselves in good faith try to help upward toward peace and order those of our sister republics which need such help. Just as there has been a gradual growth of the ethical element in the relations of one individual to another, so we are, even though slowly, more and more coming to recognize the duty of bearing one another's burdens, not only as individuals, but also as among nations.

Santo Domingo, in her turn, has now made an appeal to us to help her, and not only every principle of

$$
\text { [128] }
$$




\section{APPENDIX}

wisdom but every generous instinct within us bids us respond to the appeal. It is not of the slightest consequence whether we grant the aid needed by Santo Domingo as an incident to the wise development of the Monroe Doctrine, or because we regard the case of Santo Domingo as standing wholly by itself, and to be treated as such, and not on general principles or with any reference to the Monroe Doctrine. The important point is to give the needed aid, and the case is certainly sufficiently peculiar to deserve to be judged purely on its own merits. (59th Congress, 1 st session, 1905, House Documents, Foreign Relations, No. 4941 .)

\section{(d)}

The Second International Conference of American Republics, held in Mexico in the years 1901-02, provided for the holding of the third conference within five years, and committed the fixing of the time and place and the arrangements for the conference to the governing board of the Bureau of A merican Republics, composed of the representatives of all the American nations in Washington. That board discharged the duty imposerl upon it with marked fidelity and painstaking care, and upon the courteous invitation of the United States of Brazil, the conference was held at Rio de Janeiro, continuing from the 23d of July to the 29th of August last. Many subjects of common interest to all the American nations were discussed by the conference, and the conclusions reached, embodied in a series of resolutions and proposed conventions, will be laid before you upon the coming in of the final report of the American delegates. They contain many matters of importance relating to the extension of trade, the

$$
\text { [129] }
$$




\section{APPENDIX}

increase of communication, the smoothing away of barriers to free intercourse, and the promotion of a better knowledge and good understanding between the different countries represented. The meetings of the conference were harmonious and the conclusions were reached with substantial unanimity. It is interesting to observe that in the successive conferences which have been held the representatives of the different American nations have been learning to work together effectively, for, while the First Conference in Washington in 1889, and the Second Conference in Mexico in 1901-02, occupied many months, with much time wasted in an unregulated and fruitless discussion, the Third Conference at Rio exhibited much of the facility in the practical dispatch of business which characterizes permanent deliberative bodies, and completed its labors within the period of six weeks originally allotted for its sessions.

Quite apart from the specific value of the conclusions reached by the conference, the example of the representatives of all the American nations engaging in harmonious and kindly consideration and discussion of subjects of common interest is itself of great and substantial value for the promotion of reasonable and considerate treatment of all international questions. The thanks of this country are due to the Government of Brazil and to the people of Rio de Janeiro for the generous hospitality with which our delegates, in common with the others, were received, entertained, and facilitated in their work.

Incidentally to the meeting of the conference, the Secretary of State visited the city of Rio de Janeiro, and was cordially received by the conference, of which

$$
\text { [130] }
$$




\section{APPENDIX}

he was made an honorary president. The announcement of his intention to make this visit was followed by most courteous and urgent invitations from nearly all the countries of South America to visit them as the guest of their Governments. It was deemed that by the acceptance of these invitations we might appropriately express the real respect and friendship in which we hold our sister Republics of the southern continent, and the Secretary, accordingly, visited Brazil, Uruguay, Argentina, Chile, Peru, Panama, and Colombia. He refrained from visiting Paraguay, Bolivia, and Ecuador only because the distance of their capitals from the seaboard made it impracticable with the time at his disposal. He carried with him a message of peace and friendship, and of strong desire for good understanding and mutual helpfulness; and he was everywhere received in the spirit of his message. The members of government, the press, the learned professions, the men of business, and the great masses of the people united every where in emphatic response to his friendly expressions and in doing honor to the country and cause which he represented.

In many parts of South America there has been much misunderstanding of the attitude and purposes of the United States toward the other American Republics. An idea had become prevalent that our assertion of the Monroe Doctrine implied, or carried with it, an assumption of superiority, and of a light to exercise some kind of protectorate over the countries to whose territory that doctrine applies. Nothing could be farther fiom the truth. Yet that impression continued to be a serious barrier to good understanding, to friendly intercourse, to the introduction of Amer-

$$
\left[\begin{array}{l}
131
\end{array}\right]
$$




\section{APPENDIX}

ican capital and the extension of American trade. The impression was so widespread that apparently it could not be reached by any ordinary means.

It was part of Secretary Root's mission to dispel this unfounded impression, and there is just cause to believe that he has succeeded. In an address to the third conference at Rio on the 31 st of July - an address of such note that I send it in, together with this message - he said :

"We wish for no victories but those of peace; for no territory except our own; for no sovereignty except the sovereignty over ourselves. We deem the independence and equal rights of the smallest and weakest member of the family of nations entitled to as much respect as those of the greatest empire, and we deem the observance of that respect the chief guaranty of the weak against the oppression of the strong. We neither claim nor desire any rights or privileges or powers that we do not freely concede to every American Republic. We wish to increase our prosperity, to extend our trade, to grow in wealth, in wisdom, and in spirit, but our conception of the true way to accomplish this is not to pull down others and profit by their ruin, but to help all friends to a common prosperity and a common growth, that we may all become greater and stronger together.

"Within a few months for the first time the recognized possessors of every foot of soil upon the American continents can be and I hope will be represented with the acknowledged rights of equal sovereign states in the great World Congress at the Hague. This will be the world's formal and final acceptance of the declaration that no part of the American continents is to

$$
\text { [132] }
$$




\section{APPENDIX}

be deemed subject to colonization. Let us pledge ourselves to aid each other in the full performance of the duty to humanity which that accepted declaration implies, so that in time the weakest and most unfortunate of our Republics may come to march with equal step by the side of the stronger and more fortunate. Let us help each other to show that for all the races of men the liberty for which we have fought and labored is the twin sister of justice and peace. Let us unite in creating and maintaining and making effective an all-American public opinion, whose power shall influence international conduct and prevent international wrong, and narrow the causes of war, and forever preserve our free lands from the burden of such armaments as are massed behind the frontiers of Europe, and bring us ever nearer to the perfection of ordered liberty. So shall come security and prosperity, production and trade, wealth, learning, the arts, and happiness for us all."

These words appear to have been received with acclaim in every part of South America. They have my hearty approval, as I am sure they will have yours, and I cannot be wrong in the conviction that they correctly represent the sentiments of the whole American people. I cannot better characterize the true attitude of the United States in its assertion of the Monroe Doctrine than in the words of the distinguished former minister of foreign affairs of Argentina, Doctor Drago, in his speech welcoming Mr. Root to Buenos Ayres. He spoke of -

"The traditional policy of the United States (which) without accentuating superiority or seeking preponderance, condemned the oppression of the na-

$$
\text { [13.3] }
$$




\section{APPENDIX}

tions of this part of the world and the control of their destinies by the great Powers of Europe."

It is gratifying to know that in the great city of Buenos Ayres, upon the arches which spanned the streets, entwined with Argentine and American flags for the reception of our representative, there were emblazoned not only the names of Washington and Jefferson and Marshall, but also, in appreciative recognition of their services to the cause of South American independence, the names of James Monroe, John Quincy Adams, Henry Clay, and Richard Rush. We take especial pleasure in the graceful courtesy of the Government of Brazil, which has given to the beautiful and stately building first used for the meeting of the conference the name of "Palacio Monroe." Our grateful acknowledgments are due to the Governments and the people of all the countries visited by the Secretary of State for the courtesy, the friendship, and the honor shown to our country in their generous hospitality to him. (59th Congress, $2 d$ session, 1906, House Documents, vol. 1, pt. 1, No. 1, Foreign Relations, No. 5104.)

\section{III}

\section{THE MONROE DOCTRINE AT ITS BEST}

BEING THE SPEECH OF SECRETARY ROOT

AT RIO DE JANEIRO, JULY 31, 1906

Mr. President, and Gentlemen of the Third Conference of American Republics : I beg you to believe that I highly appreciate and thank you for the honor you do me.

$$
[134]
$$




\section{APPENDIX}

I bring from my country a special greeting to her elder sisters in the civilization of America.

Unlike as we are in many respects, we are alike in this, that we are all engaged under new conditions and free from the traditional forms and limitations of the Old World in working out the same problem of popular self-government.

It is a difficult and laborious task for each of us. Not in one generation nor in one century can the effective control of a superior sovereign, so long deemed necessary to government, be rejected and effective selfcontrol by the governed be perfected in its place. The first fruits of democracy are many of them crude and unlovely; its mistakes are many, its partial failures many, its sins not few. Capacity for self-government does not come to man by nature. It is an art to be learned, and it is also an expression of character to be developed among all the thousands of men who exercise popular sovereignty.

To reach the goal towards which we are pressing forward, the governing multitude must first acquire knowledge that comes from universal education, wisdom that follows practical experience, personal independence and self-respect befitting men who acknowledge no superior, self-control to replace that external control which a democracy rejects, respect for law, obedience to the lawful expressions of the public will, consideration for the opinions and interests of others erually entitled to a voice in the state, loyalty to that abstract conception - one's country - as inspiring as that loyalty to personal sovereigns which has so illumined the pages of history, subordination of personal interests to the public good, love of justice and mercy,

$$
\text { [135] }
$$




\section{APPENDIX}

of liberty and order. All these we must seek by slow and patient effort; and of how many shortcomings in his own land and among his own people each one of us is conscious.

Yet no student of our times can fail to see that not America alone, but the whole civilized world is swinging away from its old governmental moorings and intrusting the fate of its civilization to the capacity of the popular mass to govern. By this pathway mankind is to travel, whithersoever it leads. Upon the success of this our great undertaking the hope of humanity depends.

Nor can we fail to see that the world makes substantial progress towards more perfect popular self-government.

I believe it to be true that, viewed against the background of conditions a century, a generation, a decade ago, government in my own country has advanced, in the intelligent participation of the great mass of the people, in the fidelity and honesty with which they are represented, in respect for law, in obedience to the dictates of a sound morality, and in effectiveness and purity of administration.

Nowhere in the world has this progress been more marked than in Latin America. Out of the wrack of Indian fighting and race conflicts and civil wars, strong and stable governments have arisen. Peaceful succession in accord with the people's will has replaced the forcible seizure of power permitted by the people's indifference. Loyalty to country, its peace, its dignity, its honor, has risen above partisanship for individual leaders. The rule of law supersedes the rule of man. Property is protected and the fruits of enterprise are secure. Individual liberty is respected. Continuous public policies are

$$
\text { [136] }
$$




\section{APPENDIX}

followed; national faith is held sacred. Progress has not been equal everywhere, but there has been progress everywhere. The movement in the right direction is general. The right tendency is not exceptional; it is continental. The present affords just cause for satisfaction; the future is bright with hope.

It is not by national isolation that these results have been accomplished, or that this progress can be continued. No nation can live unto itself alone and continue to live. Each nation's growth is a part of the development of the race. There may be leaders and there may be laggards, but no nation can long continue very far in advance of the general progress of mankind, and no nation that is not doomed to extinction can remain very far behind. It is with nations as it is with individual men : intercourse, association, correction of egotism by the influence of other's judgment, broadening of views by the experience and thought of equals, acceptance of the moral standards of a community the desire for whose good opinion lends a sanction to the rules of right conduct - these are theconditions of growth in civilization. A people whose minds are not open to the lessons of the world's progress, whose spirits are not stirred by the aspirations and the achievements of humanity struggling the world over for liberty and justice, must be left behind by civilization in its stearly and beneficent advance.

To promote this mutual interchange and assistance between the American Republics, engaged in the same great task, inspired by the same purpose, and professing the same principles, I understand to be the function of the American Conference now in session. There is not one of all our countries that cannot benefit the others; there is not one that cannot receive benefit from

$$
\text { [137] }
$$




\section{APPENDIX}

the others; there is not one that will not gain by the prosperity, the peace, the happiness of all.

According to your programme no great and impressive single thing is to be done by you ; no political questions are to be discussed; no controversies are to be settled; no judgment is to be passed upon the conduct of any state; but many subjects are to be considered which afford the possibility of removing barriers to intercourse; of ascertaining for the common benefit what advances have been made by each nation in knowledge, in experience, in enterprise, in the solution of difficult questions of government, and in ethical standards; of perfecting our knowledge of each other; and of doing away with the misconceptions, the misunderstandings, and the resultant prejudices that are such fruitful sources of controversy.

And thereare some subjects in the programme which invite discussion that may lead the American Republics towards an agreement upon principles, the general practical application of which can come only in the future through long and patient effort. Some advance at least may be made here towards the complete rule of justice and peace among nations in lieu of force and war.

The association of so many eminent men from all the Republics, leaders of opinion in their own homes; the friendships that will arise among you ; the habit of temperate and kindly discussion of matters of common interest; the ascertainment of common sympathies and aims; the dissipation of misunderstandings; the exhibition to all the American peoples of this peaceful and considerate method of conferring upon international questions - this alone, quite irrespective of the resolu-

$$
\text { [ } 138]
$$




\section{APPENDIX}

tions you may adopt and the conventions you may sign, will mark a substantial advance in the direction of international good understanding.

These beneficent results the Government and the people of the United States of America greatly desire.

We wish for no victories but those of peace; for no territory except our own; for no sovereignty except the sovereignty over ourselves. We deem the independence and equal rights of the smallest and weakest member of the family of nations entitled to as much respect as those of the greatest empire, and we deem the observance of that respect the chief guaranty of the weak against the oppression of the strong. We neither claim nor desire any rights, or privileges, or powers that we do not freely concede to every American Republic. We wish to increase our prosperity, to expand our trade, to grow in wealth, in wisdom, and in spirit, but our conception of the true way to accomplish this is not to pull down others and profit by their ruin, but to help all friends to a common prosperity and a common growth, that we may all become greater and stronger together.

Within a few months, for the first time, the recognized possessors of every foot of soil upon the American continents can be and I hope will be represented with the acknowledged rights of equal sovereign states in the great World Congress at the Hague. This will be the world's formal and final acceptance of the declaration that no part of the American continents is to be deemed subject to colonization. Let us pledge ourselves to aid each other in the full performance of the duty to humanity which that accepted declaration implies; so that in time the weakest and most unfortu-

$$
\text { [139] }
$$




\section{APPENDIX}

nate of our Republics may come to march with equal step by the side of the stronger and more fortunate. Let us help each other to show that for all the races of men the liberty for which we have fought and labored is the twin sister of justice and peace. Let us unite in creating and maintaining and making effective an all-American public opinion, whose power shall influence international conduct and prevent international wrong, and narrow the causes of war, and forever preserve our free lands from the burden of such armaments as are massed behind the frontiers of Europe, and bring us ever nearer to the perfection of ordered liberty. So shall come security and prosperity, production and trade, wealth, learning, the arts, and happiness for us all.

Not in a single conference, nor by a single effort, can very much be done. You labor more for the future than for the present; but if the right impulse be given, if the right tendency be established, the work you do here will go on among all the millions of people in the American continents long after your final adjournment, long after your lives, with incalculable benefit to all our beloved countries, which may it please God to continue free and independent and happy for ages to come. (Speeches incident to the Visit of Secretary Root to South America, Washington, 1906, pp.7-13.)

\section{[140]}




\section{APPENDIX}

IV

\section{THE LAST PHASE}

\section{THE LODGE RESOLUTION}

Resolved that when any harbor or other place in the American continents is so situated that the occupation thereof for naval or military purposes might threaten the communications or the safety of the United Slates, the Government of the United States could not see, without grave concern, the possession of such harbor or other place by any corporation or association which has such a relation to another Government, not American, as to give that Government practical power of control for national purposes.

Mr. President, ... this resolution rests on a generally accepted principle of the law of nations, older than the Monroe Doctrine. It rests on the principle that every nation has a right to protect its own safety, and that if it feels that the possession by a foreign power, for military or naval purposes, of any given harbor or place is prejudicial to its safety, it is its duty as well as its right to interfere.

I will instance as an example of what I mean the protest that was made successfully against the occupation of the port of Agadir in Morocco by Germany. England objected on the ground that it threatened her communication through the Mediterranean. That view was shared largely by the European powers, and the occupation of that port was prevented in that way. That is the principle upon which the resolution rests.

It has been made necessary by a change of modern conditions, under which, while a government takes no

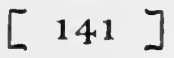




\section{APPENDIX}

action itself, the possession of an important place of the character I have described may be taken by a corporation or association which would be under the control of the foreign government.

The Monroe Doctrine was, of course, an extension in our own interests of this underlying principle- the right of every nation to provide for its own safety. The Monroe Doctrine, as we all know, was applied, so far as taking possession of territory was concerned, to its being open to further colonization, and naturally did not touch upon the precise point involved here. But without any Monroe Doctrine, the possession of a harbor such as that of Magdalena Bay, which has led to this resolution, would render it necessary, I think, to make some declaration covering a case where a corporation or association was involved.

In this particular case it became apparent from the inquiries made by the committee and by the administration that no government was concerned in taking possession of Magdalena Bay; but it also became apparent that those persons who held control of the Mexican concession, which included the land about Magdalena Bay, were engaged in negotiations which have not yet been completed certainly but which have only been tentative, looking to the sale of that bay and the land about it to a corporation either created or authorized by a foreign government, or in which the stock was largely held or controlled by foreigners.

The passage of this resolution has seemed to the committee, without division, I think, to be in the interest of peace. It is always desirable to make the position of a country in regard to a question of this kind known beforehand, and not to allow a situation to arise

$$
\text { [142] }
$$




\section{APPENDIX}

in which it might be necessary to urge a friendly power to withdraw when that withdrawal could not be made, perhaps, without some humiliation.

The Resolution is merely a statement of policy allied to the Monroe Doctrine, of course, but not necessarily dependent upon it, or growing out of it. When the message came in I made a statement as to the conditions at Magdalena Bay which had led to the resolution of inquiry and which has now led to the subsequent action of the committee. It seemed to the committee that it was very wise to make this statement of policy at this time when it can give offence to no one and makes the position of the United States clear.

Of course I need not say to the Senate that the opening of the Panama canal gives to the question of Magdalena Bay and to that of the Galapagos Islands, which have been once or twice before considered, an importance such as they have never possessed, and I think it enormously desirable in every interest that this resolution should receive the assent of the Senate. (Resolution introduced by Senator Lodge, of Massachusetts, in the Senate and passed, August 2, 1912, together with his speech in defence of it. Congressional Record, vol. 48 , part 10, page 10045.)

[The Resolution was discussed in secret session for three hours and then passer, 51-4, Senator Cummins being the leading opponent on the ground that corporations should not be included in this.]

$$
[143]
$$



I NDEX 



\section{INDEX}

"A B C" powers, 77, 78; 90; advisability of our allying with, against Asiatics, 96; 109, 110, 111.

Adams, John Quincy, 4.

Alliance, Latin-American, - defensive, 74; 77, 78, 79;

U.S. with "A B C" powers, 109, 110, 111.

Alsop claim, $35 ; 78 ; 86$.

Amazon, U. S. expedition, 33.

Ambassadors, exchange with Argentina and Chile, 110.

Antilles, 74.

Arbitration, no right to compel, 17 .

Argentina, cartoons, 31 ; 68 ; wealth and importance, 55 , $56,57,58,59,60,61,62 ; 63$; attitude toward Monroe Doctrine, 65, 67, 68, 76; navy, 78, 90; productions and exports, 58, 100; immigration, 100; ambassadors, exchange of, 110; Japanese in, 94, 95.

Asiatic exclusion policy, U. S., 95.

Asiatics in South America, 90, 91, 92, 93, 94, 95, 96.

$\mathrm{B}_{\text {AHIA, }}, 105,106$.

"Baltimore" episode, 27.

Banks, German, in South America, 99.

Barrundia affair, 25, 26.

Benham, Admiral, 29.

" Big Stick," 71.

Blaine, Secretary James G., 18.

Blanco, General Guzman, 21.

Bland, Mr., 91.

Bluefields incident, 30 .

Bolivia, Indian population, 91 ; products, 100.

Boston Chamber of Commerce, 57.

Boundary dispute, Venczucla - British Guiana, 11, 12. Brazil, French literature in, 20 ; U. S. warships sent, 1893, 28, 29, 30 ; bad feeling engenclered, 1895, 29, 30; U.S. Aniazon expedition, 33 ; wealth and importance, $55,56,58,59,60,61,62,99$; attitude to U.S., 69 ,

$$
\text { [147] }
$$




\section{INDEX}

70; nary, 79, 90; Asiatics in, 93, 94; Germans in, $98,100$.

British Guiana, boundary dispute, 11, 12.

Bryce, James, 20, 21, 82, 107, 108.

Buenos Aires, taxi-cabs in, 58; cartoons, 68.

Calderon, Francisco Garcia, 23, 75.

California, Japanese in, 63,93; annexation of, 41, 79, 107.

Canada, 73.

Canal Zone, United States takes control, 34.

Cantonese in South America, 92.

Capital, British, in South America, 61.

Cartoons, Latin-American, 31 ; Argentine, 31, 68; Chilean, $68,69$.

Central America, warships sent to, 1899, 33; our new attitude in, 38 ; U.S. troops twice landed recently, 38 ; $74 ; 111$.

Chile, war with Spain, 1866-67, 8, 9; "Itata" affair, $1891,26,27,28$; Alsop claim, 35,86 ; wealth and importance, 55, 56, 60, 61, 100 ; navy, 79, 90 ; LatinAmerican Congress, 1908, 87, 89; Asiatics in, 92 ; ambassadors, exchange with, 110 .

China, 58 ; 68 ; treaty rights, $80 ; 91$.

Chinese in Peru, 91; in Mexico, 93.

Cleveland, President Grover, 11, 13, 14, 15.

Colombia, U. S. demand for damages, 1899,33 ; U. S. property seized, 1902, 33; territory taken from, 79 ; Indian population, 91; A siatics in, 92.

Color line in United States and Latin America, 23, 24.

Commerce, see Trade.

Communication and travel, difficulties in South America to-day, 7.

Congress of American powers, 110.

Continent, synonymous with western hemisphere, 10 .

Coolidge, A. C., 7 (note).

Cuba, Spanish American War, 30 ; recent intervention in, $39,79,86 ; 41 ; 69$.

Custom houses, Latin-American, 51.

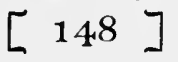




\section{INDEX}

Da Gama, Admiral, 29.

Debts, Latin-American, enforced payment, $35,36,37$, $38,43,44,45$.

“Detroit,” U.S.S., 29.

Dominican Republic, debt, 36, 37.

Ecuador, trouble with, 1899,33; present financial status, 45,$46 ; 69 ; 92$; refuses U.S. assistance in sanitation, 82,83 ; Indian population, 91 .

Grrmans in South America, 74, 98, 99, 100.

Gil, Professor, 67.

Gorgas, Colonel, 82.

Grant, U. S., General, message on Santo Domingo, 9, 10. Great Britain, Venezuela dispute, 11 ; danger of war with, 11 ; capital invested in South America, 61.

Guam, 32.

Guantanamo, 32, 40, 79.

Guatemala, Barrundia affair, 25, 26; present financial status, $45,46$.

Guayaquil, sanitation of, 82,83 .

Hague, The, 84.

"Hegemony" of North America, 71.

Holy Alliance, 6.

Honduras, U.S. warships sent, 34,35 ; comments of minister on our new attitude, $38 ; 41$; present financial status, 45,46 .

Hřdlička, Alěs, 91.

Immigration, Asiatic, 95.

Imperialism, $71,72,73,74,83,86$.

Independence, right of, 53 .

International law, difference between law and holicy, 13, $14,15,16,17$; overstepped, 26,27 ; intervention and, 54.

International Scientific Congresses, 88.

International Union of American Republics, 18.

$$
\text { [149] }
$$




\section{INDEX}

Intervention, European, forbidden by President Polk, 7; menace of, 41, 42, 78; armed, to collect debts, 43, 44; when legitimate, 54 ; cases objectionable to South America, 79; necessity of checking, 79; and interference, 82.

Investments, British, in South America, 61 .

"Itata" affair, 26, 27.

$\mathrm{J}_{\text {APAN, }} 58$.

Japanese, Magdalena Bay, 40, 92, 93; 63; 74; in South America, 90; in Brazil, 93, 94 ; labor, 95 ; steamship line, 96 ; in Peru, 96.

Jefferson, President Thomas, 71.

Jingoism, Venezuela controversy, $1895,11,12,13$; in Chile affair, 1891, 27; 67.

KNox, Secretary Philander C., 86, 87.

La Guaira, 33.

La Plata, University of, 67.

Labor, Japanese, 95.

Latin America, not sympathetic through proximity, race, or religion, $18,19,20,21,22,23,24$; financial status, $43,44,45,46,47$; naval power, 78,79 ; influenced against U.S., 89, 108; European criticism, 72, 73, 74.

Latin-American alliance against U. S. tutelage, 66,67 , $72,73,74,77,78$.

Latin-American Scientific Congress, 87, 88, 89.

Latin Crusade, 74, 77.

Lodge, Henry Cabot, 39.

Lynchings in U. S., 77.

Magdalena Bay, 39, 40, 92, 93.

Mail steamers to Argentina, 62.

Marchi, Baron de, 95.

Maximilian, 8.

Mexican War, 1846, 107.

Mexico, Napoleon III and Maximilian, 8; 25; 68; 69;

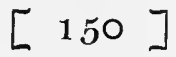




\section{INDEX}

debt, 46, 47; Texas and California, 79; U. S. army mobilized on frontier, 79 ; Chinese in, 93.

Monroe, President James, 4, 10.

Monroe Doctrine, purpose and scope of present treatise, preface, vii ; text of original Doctrine, 3, appendix; Austrian comment, 1824, 5 ; early history, 1823-66, $4,5,8$; significance early recognized in Europe, 5; when useful to Latin America, 6, 7, 107; Polk's interpretation, no European intervention allowed, 7; Seward's interpretation, (1) Maximilian, 8, (2) Chile, War of 1866, 8, 9; Grant's interpretation, Santo Domingo, 1870, 9, 10; aggressive attitude first assumed, 10 ; Olney's invocation, Venezuela, 11 ; not international law, 13, 14, 15, 16, 17; compulsory arbitration, 17; popularity in U.S. evidenced, 17 ; not concerned in "Venezuela controversy"? 17; founded on false premises, 18,19, 20, 21 , 22, 23 ; aggressive policy of 1892 dangerous, 27, 28 ; Olney's new doctrine, 30 ; comparison of original and that of $1898,32,33$; fruits of new doctrine, $32,33,34,35,36,37,38,39,40$; enforcing payment of bad debt claims, $35,36,37,38,43,44,45$; Lodge Resolution, 39 ; interference with rights of sovereign states, 40 ; heavy responsibility of $U$.S. under, $42,47,50,52,53,108,109$; U.S. made international policeman, 42, 45, 48; what it involves from two points of view, 42, 43, 44; European loans, 43, 44, 45, 46, 47 ; U.S. made international mediator, 43,50 ; invoked by Guatemala, 46; Roosevelt ontlines new bearing, 47, $48,49,50,51,52$; U. S. not obliged to prevent punishment for torts, 50,51 ; contractual obligations, 51 ; law of nations broken, 53 ; insulting from Latin-American point of view, 54 ; why not abandon? 55 ; LatinAmerican strength proved, $55,56,57,58,59,60,61$, $62,63,64$; abandonment necessary, 64 ; imperialistic, 64, 65; Argentina's attitude, 65, 67, 68; Brazil's attitude, 69 ; arms necessary for enforcement. 70 ; IatinAınerican criticisms quoted, 70, 71, 72, 73, 74, 75, 76,77 ; "Doctrine of absorption," 71 ; adverse criticism in Europe, 72, 73, 74; Peru's attitude, 73, 74, 75,86 ; "outworn shibboleth," 77 ; dangers in present

$$
[151]
$$




\section{INDEX}

tendency, 80, 81 ; Root's conciliatory policy, 83, 84, 85, 86; a selfish policy ? 89; Asiatics in South America, 96 ; selfish point of view argument, 97 ; trade affected by, $97,98,99$; circumvention by Germany in South America, 98, 99; cost to U.S. if adhered to, 102, 103, 104 ; detrimental to world's peace, 107 ; possible new policy if abandoned, 109, 112; why held so tenaciously, 111 ; hated words in South America, 112.

\section{$\mathrm{N}_{\text {APOLEON III, } 8 .}$}

Naval resources of Latin America, 78, 79.

Nicaragua, Bluefields incident, 30 ; landing U.S. troops in $1899,33,79$; present financial status, $45 ; 86$.

"North American Peril," 73.

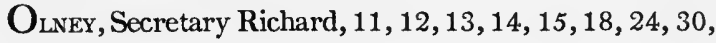
43.

Orinoco River, 28.

Pan-American Congress (Rio de Janeiro), 83, 84.

Pan-American Scientific Congress, 87, 88, 89, 110.

Pan-Americanism, 18, 19, 20, 24, 68, 92.

Pan-Hispanism, 22.

Panama, 33, 34, 41, 69, 82.

Panama Canal, 34, 40; tolls question, 80, 92.

Peace, international, 104, 105, 107.

Peru, travel in, 7; attitude to U.S., 73, 74, 75, 76, 77; to Monroe Doctrine, 83, 86; Chinese in, 91, 92 ; Japanese, 96 ; products, 100.

Phelps, E. J., 15.

Philippines, 31, 32.

Polk, President James K., 7.

Porto Rico, 32, 41, 69, 79.

Putumayo atrocities, 7, 75, 76, 77.

Rio dE Jankiro (Congress), 83.

Ritz-Carlton hotels, 57.

Roosevelt, President Theodore, 35, 38, 39, 47, 49, 50, 52,67 .

$$
\text { [ } 152]
$$




\section{INDEX}

Root, Secretary Elihu, 4; tour of Sonth America, 1906, 34 ; 53 ; 87 ; speech, $83,99,100,101,102,103,104$, $105,106$.

Russia and Alaska, 6.

SAlisbury, Lord, 12, 13.

Salvador, trouble at U.S. Legation, 1890, 26.

San Antonio, 61.

San Diego, 27.

Sanitation in Guayaquil, 82, 83.

Santo Domingo, General Grant's action concerning, 9,

10 ; U.S. intervention in, $35,36,37,41,79,86$.

São Paulo, Japanese in, 93.

Seward, Secretary William H., 8, 9.

South America, conditions, ignorance in the U.S. concerning, $8,9,18,19,57,62,63$; nearer Europe than U.S., 18, 19, 20; travel conditions in, 57 ; partition of, 96 .

South America Society in Tokyo, 94.

South American Journal (financial statistics), 61.

Spain, war with, 30,32 .

Spanish American attitude historically unfriendly, 41.

Spanish American War, 30, 31, 32.

Spanish comment, 78.

Spoliation, Act of, 45 .

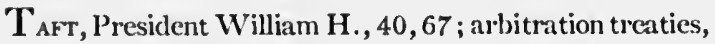
$80,81$.

Taxi-cabs in Buenos Aires, 58.

Texas, 79.

Tierra del Fuego, 67.

Trade, international, 28; in South America, 55, 56, 57, $58,59,60$; friendly feeling necessary, 97, 98 ; German monopoly in South America, 98, 99; increasing value of South America, 99, 100, 101.

'Trans-Mississippi Commercial Congress (Kansas City), 99.

$$
[153]
$$




\section{INDEX}

UGARTE, Manuel, 66, 67.

Uruguay, products, 100.

V Alparaiso, 27, 61.

Venezuela, boundary dispute, $11,12,17,30$; U.S. warships sent, 1892,$28 ; 1899,33$; U. S. intervention in 1902,$34 ; 62$.

$W_{\text {AlfFFe, Maurice de, } 72 .}$

Weyler, General, 31.

Woolsey, Professor T.S., 15, 16, 27.

"Y

Yellow fever, 82, 83.

"Yellow Peril,"' 91, 93, 96. 

$142 \quad$ University of California

SOUTHERN REGIONAL LIBRARY FACILITY

405 Hilgard Avenue, Los Angeles, CA 90024-1388

Return this material to the library from which it was borrowed. 
||$_{3}|||||||||||||||||||||||||||| 00817880$

vw

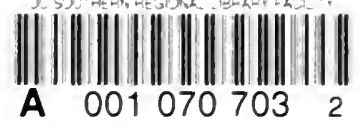


